\title{
Financial Statement Evaluation of Indian Construction Companies
}

\author{
Santanu Kumar Das, Jitendra Kumar Pattanayak
}

\begin{abstract}
This check is legitimate research fiscal summary construction employer in India. The test gives a model momentum presentation evaluation for development companies that provide criminal equipment for administrators, owners, buyers and subsidies administrative center groups to assess exhibition development businesses. fashions created to inspire the administration of the employer to settle on the precise preference. economic, conservative, and data amassed from a hundred agencies mechanical production returned to India for five years inside the beyond (2011-2015). first off recognize the requirements which are hidden in the monetary summary studies referring to India's development affiliation., preceding studies has established that there are about 21 giant percent of money related to the improvement business enterprise. This, consequently, requires the disposal of random data. Investigations aspect is the technique of reduction and grouping statistics, which may be finished within the exam-associated coins. therefore, the exam of things applied to the records amassed money development companies related to the span of five years so comes to a decision monetary markers that may be used to break up the pattern of the enterprise price range. Seven self sufficient elements, inclusive of liquidity, interest, benefits, lengthy-time period dissolvability, Asset council, inventory and efficiency are identified to be smooth for economic alternate on this country. The quit end result of this exam is the quantity of presentation, which provide exhibition organization improvement and assessment of the agency's role is determined by the use of the final survey of the dangers of article eleven through using the version Z-rating.
\end{abstract}

Keywords: Financial Ratios; Factor Analysis; Performance Grade; Performance Rating, Bankruptcy, Construction Industry.

\section{INTRODUCTION}

The development corporation acts huge work in strengthening the economic exhibition and country wide gains of a kingdom. a part of the development of everyday accounted for $7 \%$-nine $\%$ of gross domestic product (GDP) nations to create (Bakar, 2002). inside the Indian financial gadget, the regular annual dedication from enterprise improvement to GDP is simplest five-8\% .Indian surely disillusioning development employer serving the development for constantly decreased GDP a three hundred and sixty five days late because of money related emergencies. on this manner, the legislature should have a look at the economic situations of employer development and encompass despair associated sports. business development

Revised Version Manuscript Received on 10, September 2019.

Dr. Santanu Kumar Das, Assistant Professor, P.G. Department of Business Administration, Kalam Institute of Technology, Berhampur, Odisha., INDIA. And the Research Supervisor, Department of Management Studies, GIET-University, Gunupur, Odisha, India.(Email santanu.das.kumar@gmail.com)

Mr. Jitendra Kumar Pattanayak, Assistant Engineer (Civil), BMC, Berhampur and the Doctoral Student, Department of Management Studies, GIET-University, Gunupur, Odisha, India(Email: jitucivil2@ gmail.com) to provide the ground the other manner up and courting to the the the front to assist the progress of other financial regions Abdullah (1990). Be that as it could, as an extended manner as sturdiness consistent enterprise development groups face the identical excessive diploma of enterprise disappointments assessment with special groups (Yin, 2006). In the united states (US) enterprise development, the regular rate of unhappiness from 1989 to 2002 is set $14 \%$ higher than the ordinary velocity of a unhappiness for all organizations, a comparable miracle took place in Malaysia, the relative sadness of the tempo of improvement corporation India much less but maintain low advantages. Organizational development has been seen as very unstable, to have a prone overseas money-associated function and turn out to be depending on massive business cycle variations. furthermore, the charge of not unusual stock will overheat even as the economic system is developing hastily, and after destruction that once the financial system have become in decline (Wagle, 2006). evaluation Implementation of enterprise improvement "gets its which means from the way that the sector is now shifting unexpectedly in the direction of globalization. In this situation all inclusive, many corporations worldwide are given a business in countries that vary in in which they compete with environmental agencies. each agencies are worldwide development and nearby should really assume increasing their exhibition so you can hold their repute for the duration of the arena. This evaluation may be very beneficial for the proprietor, head, investor, and subsidies place of business of an corporation for one greater draw the precise position of the organisation, many models are created to assess the enterprise " execution, but some of them reflect onconsideration on low-priced and present day adjustments in their fashions. on this manner, the primary intention of this studies is to construct a presentation record associated cash exams determine the cutting-edge organization is to assemble a file of the exhibition which verify the economic scenario in business enterprise improvement businesses to take into account the factors which are low cost and buddies sizes. the percentage of the finances to evaluate various components of the organisation and a amazing bite of economic summary examination. there's a miles greater share of the standards used to assess the state of the general fee range of the association. related to the proportion of cash used by the board of administrators in a enterprise, the capability traders of the company, lender associations and enterprise researchers to research the excellent and shortcomings of the state of affairs of the

Published By:

Blue Eyes Intelligence Engineering

\& Sciences Publication

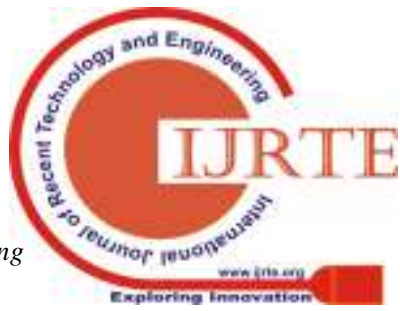


employer in industrial organization development thinking about factors practical and duration of the buddies.

\section{RELATIONSHIP BETWEEN THE CONSTRUCTION INDUSTRY AND GROWTH OF NATIONAL INCOME \& RESULTS}

The improvement venture is a basic supporter of the development of any countrywide money related framework and is promptly stricken by the specialists suggestions as governments regularly direct the financial framework by method for diminishing lower back on open creation works for the length of stagnation interims. Past examinations in various worldwide spots demonstrate that it is likewise fundamental to urge producing exercises to escape stagnation as creation quickly impacts around 200 unique segments. Indian money related framework wind up experiencing the Asian emergencies in absolute most recent one year 2014 and yet it enduring with. The impact at the blast of approach association is hero we will take a gander at qualities from underneath table1.1.The increment of appearance area that is represented a middle of five-eight\% sooner than year2013 and it's far sudden dropped to 4.Five\% inside the year2 014 we will test from Fig 1.2. Gloom of Indian forex prompted decently evaluated emergencies inside the usa of america in September 2014 and February 2015 influenced the majority of the areas altogether. Indian specialists genuinely focused the financial emergencies in directly coming charge assortment making arrangements especially with low expansion costs, low - fiscal association credit costs basically so government would like to recover going before capacity as appropriately. The ones money related components give us a form to watch the past improvements to charge the general execution and to assess our presentation inside the venture. Hence the inventive technique as a primary concern for guaging the general execution of the endeavor, the view of the presentation of the improvement business is pivotal.

Table 1.1: Micro macro economic factors:

\begin{tabular}{|c|c|c|c|c|}
\hline \multirow{2}{*}{ Year } & \multicolumn{2}{|c|}{$\begin{array}{l}\text { GDP Growth Vs } \\
\text { Construction sector } \\
\text { growth in India: }\end{array}$} & \multicolumn{2}{|c|}{$\begin{array}{l}\text { Micro economic } \\
\text { factors : }\end{array}$} \\
\hline & $\begin{array}{l}\text { Growth } \\
\text { of GDP } \\
\%\end{array}$ & $\begin{array}{l}\text { Growth of } \\
\text { construction } \\
\text { sector \% }\end{array}$ & $\begin{array}{l}\text { Interest } \\
\text { Rates } \\
\%\end{array}$ & $\begin{array}{l}\text { Inflation } \\
\text { Rates \% }\end{array}$ \\
\hline $2007-08$ & 7.5 & 7.1 & 10.5 & 3.3 \\
\hline 2008-09 & 9 & 7.4 & 11 & 7.65 \\
\hline 2009-10 & 9.4 & 8 & 9.8 & 5.69 \\
\hline 2010-11 & 9 & 8.4 & 11.5 & 5.25 \\
\hline 2011-12 & 6.7 & 8.7 & 13 & 9.5 \\
\hline 2012-13 & 8.2 & 8.9 & 11.5 & 10 \\
\hline 2013-14 & 7.8 & 8 & 10.5 & 11.5 \\
\hline 2014-15 & 6.9 & 4.8 & 9.8 & 7.5 \\
\hline & & & & \\
\hline
\end{tabular}

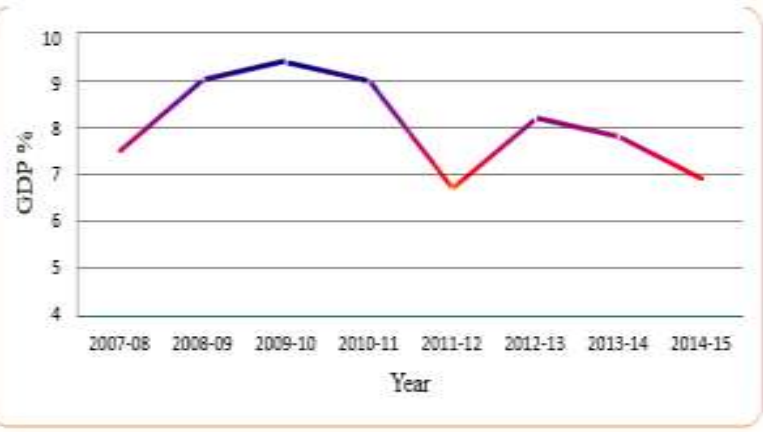

Fig 1.1 GDP growth rate

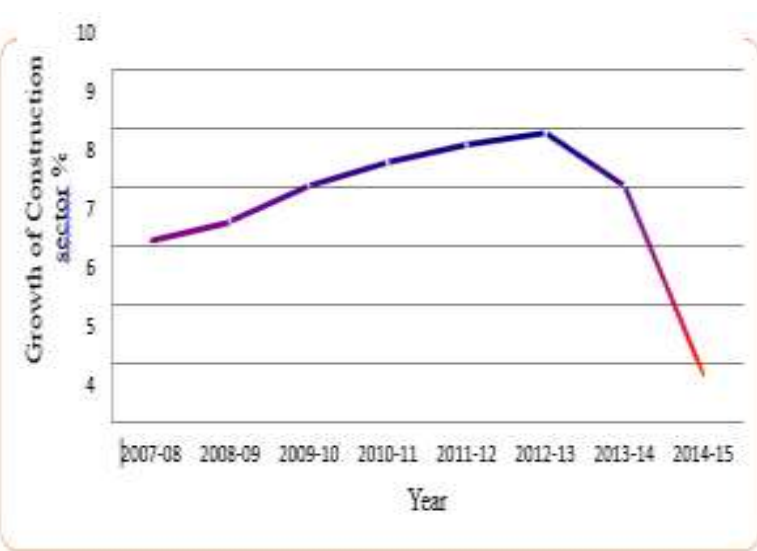

Fig 12 Constructice growth rate

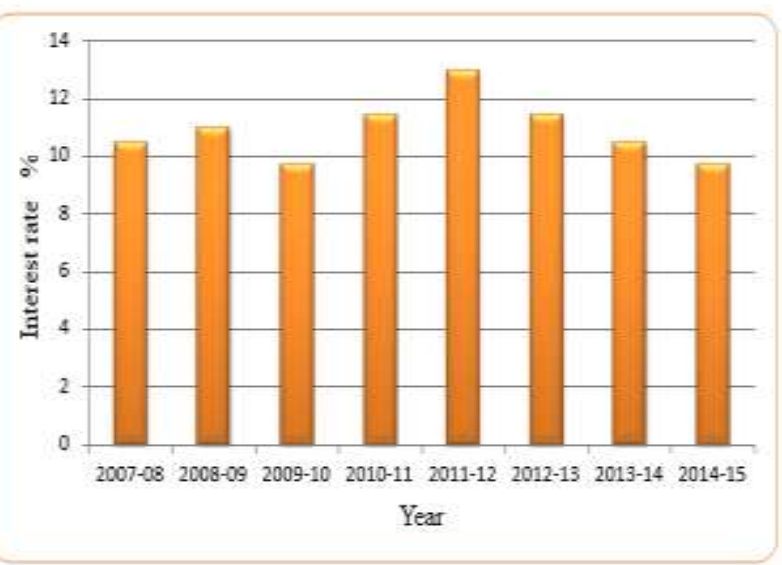

Fig 1.3 Interest rates

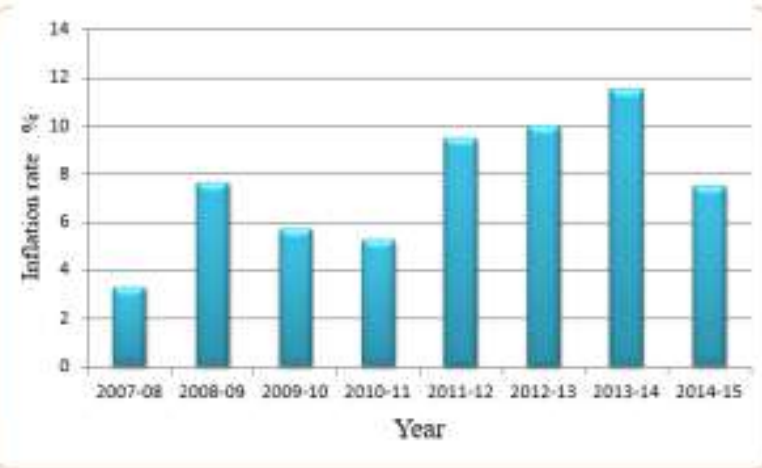

Fig 1.4 Inflation rates 


\section{LITERATURE REVIEW}

As in keeping with Moyer et al. (2011), the exam of the proportion of the price range used for 3 precept desires: (1) as a systematic instrument to distinguish the tremendous and the lack of a company in order that it could have a look at the practicality and to determine whether or not or no longer the high-quality effects can be acquired from the threat taken (2) as a system tests for make certain that the purpose of ideal corporation with an asset; and (3) as a possible tool in seeking to gain organizational dreams.

Suberi (2011) tried to discover coins-related welfare agencies in Malaysia production agencies by way of using the use of the correlation relative percent of the finances execution inspection agencies collectively with inspection execution all through severa companies to which he selected six organizations find 17 percentage financial improvement for a long term; additionally gathered facts protected conferences with delegates from six corporations respondents. At lengthy very last survey is deliberate. He reasoned that the general implementation of the development business enterprise was by using all money owed beneath normal company. With the proportion of liquidity-energy, cash and they may lack capital to again their development efforts, and sturdy signs and symptoms and signs that organizations will face a scarcity of capital and financial troubles later.

Singh et al. (2010) stated that the monetary ruin select model of development businesses, it very well may be taken into consideration that a model based totally on the share of financial simply supply a sign, no longer calculation upcoming implementation of the business enterprise, and that the rate variety version that is appropriate for the construction of the organisation continues to develop and hidden.

Edmund (1994) has tried to offer some of the cash related to the control and the essential organizer of smaller agencies. Bookkeeping challenge on a ordinary basis following ultra-modern there do plan expenditure incurred .The concept bookkeeping series supplied .also served premise investigation percentage for overhead calculation, charging share, and one of a kind key elements that allow examination with exquisite groups.

As in keeping with Moyer et al. (2011), an examination share of the finances used to address three crucial goals. to start with, it is used as a tool that is systematic in distinguishing functions and deficiencies of the enterprise employer such as to survey the equity of a non-stop try to determine whether or not or now not money back or a laugh can be received at the hazard taken. 2 nd, associated with the share of treasured money as checking devices to make sure best commercial enterprise agency focused with the useful resource of the asset. 0.33 , the percentage of financial bear in thoughts a completely interesting interest in trying to gain organizational goals. financial percent is the connection that recommend the business enterprise. the proportion of the budget to empower investigators to make money exam concerning the circumstance of the organization after a while or connect with a one of a kind organisation.

Ocal et al. (2005) suggests that the percentage of cash associated not best allow inspection employer with a economic presentation opponent within the identical business enterprise but similarly allow that industrial agency itself after a while.

James Clausen (2009), he revealed that the inspection ratio clarification payroll and accounting opinions are used to degree the execution agency blessings. He stated the studies determined motives proportion of salaries and asset reviews. Paying proclamation and accounting critiques are reviews that display huge benefits and widespread property of the agency. The studies indicates how properly the employer doing about the blessings contrasts with gives. $\mathrm{He}$ additionally suggests how well the blessings of performing up to now create sales. He characterizes revenue rationalization confirmed a net advantage of agencies thru reducing the cost of gross blessings.

\section{Research Methodology}

The technique in my examination completed after this way:

$\square$ A precis of the agency of an effective plan to participate in improvement; decide skills together with Scope, jogging age nature of the enterprise.

$\square$ monetary reasons to 100 corporations in development for a long time from 2011 to 2015 had been accumulated.

$\square$ Calculate the percentage of the budget for the economic reviews amassed above with the useful resource of using a database passed expectancies.

$\square$ To direct examination of the elements with the aid of the use of SPSS programming to recognize the crucial proportion who contributed plenty to the improvement of the affiliation.

$\square$ To construct a version to ensure the assessment of the exhibition and the location of an business enterprise relies upon on the implementation of the magnificence, the development of measures for improvement of the model acting in fig 1.four

V For organizational separation quarter organization by the use of the Z-rating version bankruptcy eleven forecast. 


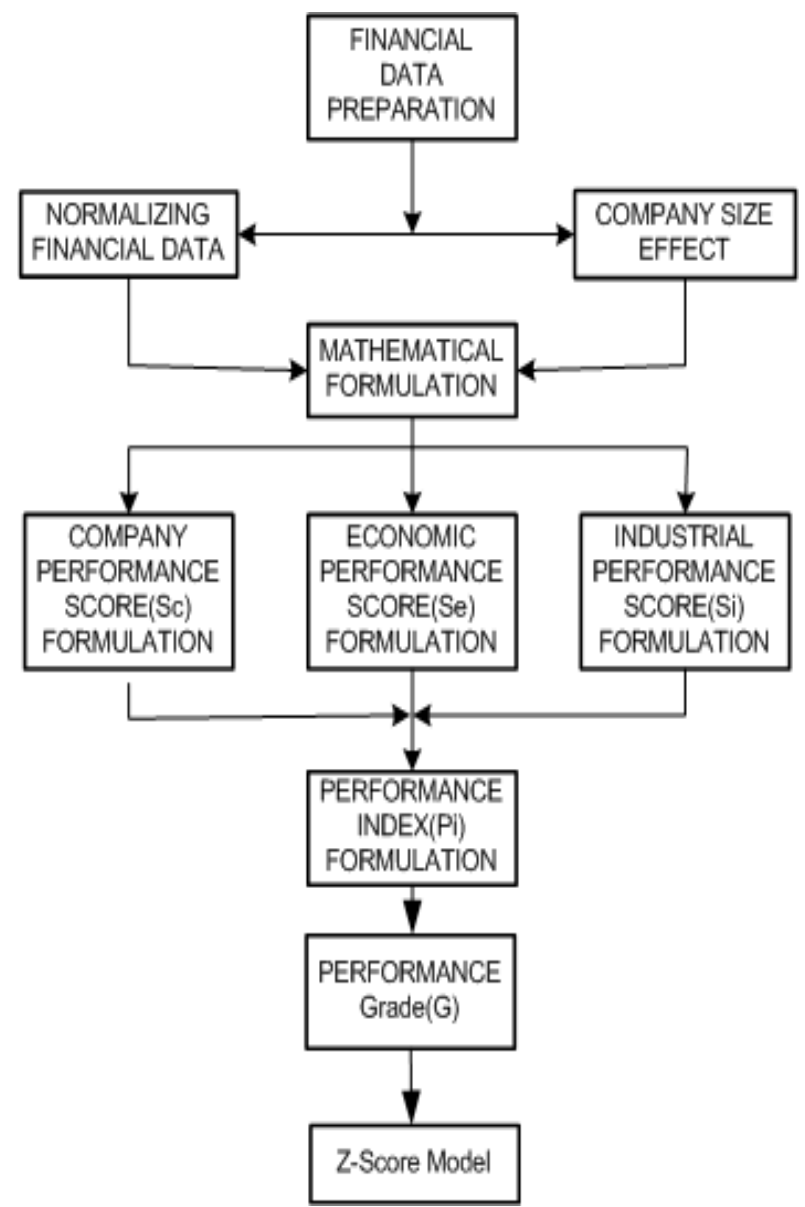

\section{DATA COLLECTION}

I actually have selected an overview of the a hundred businesses that are part of the development. Www.Fundoodata.Com legitimate web web page guide to pick companies in accordance with our requirements which includes the form of enterprise, regional, organizational elements, turnover, a type of additives and so on. financial file for 5 back to years ago (2011-15) collected from the first rate internet website online of the organization or part of an company does now not distribute on their net page all matters considered organizational statistics accrued from the NSE www.Moneycontrol.Com,

http://economictimes.indiatimes.com/internet site accommodating to collect data related to cash (monetary notes, earnings and misfortune explanation, the proclamation of income) of the company with the required length.

Fig 1.5 Flow chart of model creation process (Source:

Elamany et al. (2007), ASCE, 133:8 (576))

\begin{tabular}{|l|l|l|l|}
\hline 1 & Acrow India Limited & 26 & Garnet Constructions Limited \\
\hline 2 & Akruti Nirman Limited & 27 & Gayatri Projects Limited \\
\hline 3 & Anant Raj Industries Limited & 28 & GMR Infrastructure Limited \\
\hline 4 & Ansal Buildwell Limited & 29 & HB Estate Developers Limited \\
\hline 5 & Ansal Housing \& Construction Limited & 30 & Hindustan Construction Company Limited \\
\hline 7 & Ansal Properties \& Infrastructures Limited & 31 & $\begin{array}{l}\text { Housing Development \& Infrastructures } \\
\text { Development }\end{array}$ \\
\hline 8 & Arihant Foundations \& Housing Limited & 32 & Ircon International Limited \\
\hline 9 & Artson Engineering Limited & 33 & ITD Cementation (India) Limited \\
\hline 10 & Ashiana Housing \& Finance (India) Limited & 34 & IVR Prime Urban Developers Limited \\
\hline 11 & Atlanta Limited & 35 & IVRCL Infrastructure \& Projects Limited \\
\hline 12 & B L Kashyap \& Sons Limited & 36 & Jaihind Projects Limited \\
\hline 13 & Bhagheeratha Engineering Limited & 37 & Jai Prakash Associates Limited \\
\hline 14 & C \& C Constructions Limited & 38 & JMC Projects (India) Limited \\
\hline 15 & Consolidated Construction Consortium & 39 & Kamanwala Housing \& \\
\hline 16 & Limited & & Limited \\
\hline 17 & CCAP Limited & 40 & KEC Infrastructures Limited \\
\hline 18 & D S Kulkarni Developers Limited & 41 & KCP Limited \\
\hline 19 & DCM limited & 42 & Lanco Infratech Limited \\
\hline 20 & Dhurv Estates Limited & 43 & Lancor Holdings Limited \\
\hline 21 & ELF limited & 44 & Larsen \& Toubro Limited \\
\hline 22 & Eloco Housing \& Industries Limited & 46 & Lok Housing \& Constructions Limited \\
\hline 23 & Engineers India Limited & 47 & Mahindra Lifespaces Limited \\
\hline 24 & Era Constructions (India) Limited & 48 & Marg Constructions Limited \\
\hline 25 & Gammon India Limited & Martin Burn Limited \\
\hline
\end{tabular}




\begin{tabular}{|l|l|l|l|}
\hline 51 & MSK Projects (India) Limited & 76 & Ruchi Infrastructures Limited \\
\hline 52 & Nagarjuna Construction Company Limited & 77 & SAAGRR Infrastructures Limited \\
\hline 53 & Narendra Properties Limited & 78 & Simplex Infrastructures Limited \\
\hline 54 & Navkar Builders Limited & 79 & Simplex Projects Limited \\
\hline 55 & Nila Infrastructures Limited & 80 & Sobha Developers Limited \\
\hline 56 & Noida Toll Bridge Company Limited & 81 & Soma constructions \\
\hline 57 & Omaxe Limited & 82 & $\begin{array}{l}\text { Sriniwas Shipping \& Property Development } \\
\text { Limited }\end{array}$ \\
\hline 58 & Orbit Corporation Limited & 83 & Subhash Projects \& Marketing Limited \\
\hline 59 & Parsvnath Developers Limited & 84 & Regaliaa Realty Limited \\
\hline 60 & Patel Engineering Limited & 85 & Tantia Constructions Limited \\
\hline 61 & PBA Infrastructures Limited & 86 & Templex infraprojects Ltd \\
\hline 62 & Peninsula Land Limited & 87 & Thakkers Developers Limited \\
\hline 63 & Petron Engineering Construction Limited & 88 & Trenchless engineering services pvt Ltd \\
\hline 64 & Prajay Engineers Syndicate Limited & 89 & Trinetra infra ventures Ltd \\
\hline 65 & Prathiba Industries Limited & 90 & Tribhuvan Housing Limited \\
\hline 66 & Praveen Properties Limited & 91 & $\begin{array}{l}\text { UB Holdings Limited } \\
\text { Properties \& Holdings }\end{array}$ \\
\hline 67 & Prime Property Development Corporation & 92 & Uniquest infra ventures pvt Ltd \\
\hline 68 & Punj Lloyd Limited & 93 & Unitech Limited \\
\hline 69 & Puravankara Projects Limited & 94 & Unity Infra Projects Limited \\
\hline 70 & Radhe Developers (India) Limited & 95 & Valecha Engineering Limited \\
\hline 71 & Raghava Estates Limited & 96 & Viaton infrastructures pvt Ltd \\
\hline 72 & Rainbow Foundations Limited & 97 & Victoria Enterprises Ltd \\
\hline 73 & Rander Corporation Limited & 98 & Vijay Shanti Builders Limited \\
\hline 74 & Reliance Industrial Infrastructures Limited & 99 & Vipul Infrastructure Developers Limited \\
\hline 75 & Roman Tarmat Limited & 100 & Wirtgen India Pvt ltd \\
\hline
\end{tabular}

\section{RATIO ANALYSIS}

Testers utilize the finances related proportion of cash to peer the exceptional and shortages in special companies. associated cash is a pointer to assist enforcement proportion declared and financial instances. maximum of percent may be determined from giving a summary of the budget. financial proportions can be used to dissect and contrast patterns of company finance with people from special organizations the proportion of the budget is a magnifying device that lets in us to look past the raw numbers and discover what surely occurred. while dissect this percent continually, for the reason that the share has not some thing to provide the whole tale and that the model for each proportions vary for every industry. For our state of affairs, one hundred businesses brief improvement recorded for the examination proportions. Wrote the look at positioned that the records is adequate multi-12 months monetary percent might quantity to an approximate estimate of the affiliation. therefore, a critical requirement is that those corporations need to participate today in the work of the us of a's economic system, and furthermore they want to have a 5-year reputation within the commercial enterprise. utilizing the inverse of the information base exceeds expectations decide the share of the organisation's financial document. The improvement of the association, 21 the share in their monetary decided on as the chase:

\section{LIQUIDITY RATIOS:}

contemporary proportion, percentage speedy, coins percentage, percent components

SOLVENCY RATIOS:
Debt Asset Ratio, the share of the charge of debt, debt to add up the fee, the inclusion of coins float, debt to add up to the share of capital, the proportion of inclusions inventory.

\section{PROFITABILITY RATIOS::}

Pre share of the price blessings, go returned on all out resources, return on belongings fixed rate running Capital, Dividend Payout Ratio, ROR on total fairness

\section{EFFICIENCY RATIOS:}

Turnover T.A share, percentage Turnover F.A, Capital turns, working capital turns, finished product inventory turnover.

\subsection{HORIZANTAL \& VERTICAL PROFILEANALYSIS (HV ANALYSIS):}

monetary fineness and extraordinary proportions of information throughout the pinnacle of the organisation and period. This gives a records board which problems to supply to increase activity, and finally show off financial, of any commercial agency. two types of tests proportions integrate studies and research vertical diploma.

the share exam specifically research and even vertical pressure us to decide the fantastic and the weakness of the percentage of the business enterprise may be viably exploited to discover

$\square$ Is the motion plan is profitable?

$\square$ can we make use of powerful belongings and assets?

$\square$ Are we destined for the fulfillment of improvement? 


\section{Horizontal Analysis}

Even investigations speak modifications among intervals as price lists for every document within the precis budget. Recipes vital for the research price of change of a charge same to the evaluation among the current time frame and the past period remoted with past durations.

Vertical Analysis

Vertical communication charge range summary inquiry as a tribe. On monetary notes, distribute one hundred\% absolute supply and the articulation of wages, all out sales is allotted $100 \%$ and supporters of different proportions of the time it broke down.

\subsection{Horizontal Analysis:}

contextual evaluation: Larsen and Toubro constrained supply us an possibility to consider the example of Larsen and Toubro restricted to our research and ruin their shows on a diploma plane. research is as in step with the following:

\subsubsection{Net profit growth rate}

frequently mentioned as a first-rate situation, internet income is decided through subtracting the whole price of income businesses all out, then show what the enterprise has received in the given time body. In business and fund accounting, internet income identical to the gross benefit minus interest payable plus one off items for a given time period. In simplistic terms, net profit is the money left over after paying all the expenses of an endeavour.

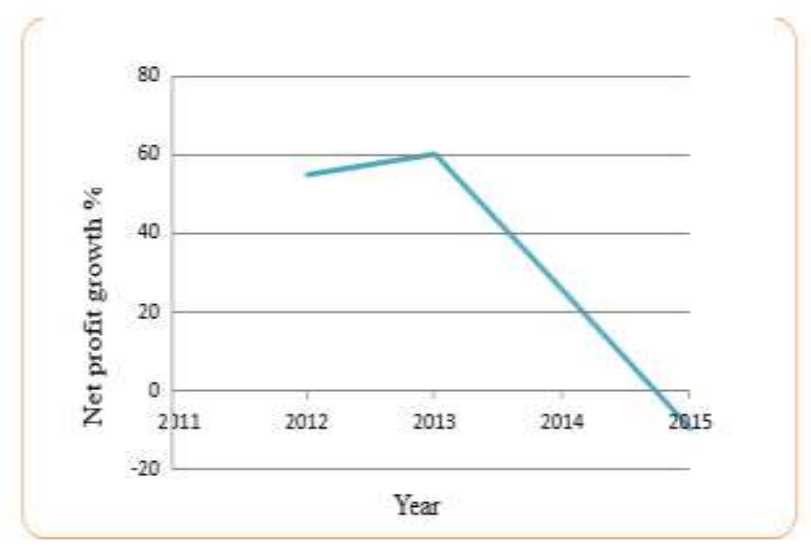

Fig 4.3.1 Net profit growth rate

frequently, the benefits of Operations and internet blessings are usually interrelated corporations. The graph shows that Larsen and Toubro restrained in from more than one years of ongoing struggle with again salting price of development blessings are low, there may be a surprising fall of the 12 months 2013-2015 might be a important cause pressure of national monetary inclinations helpless.

\subsection{2 earnings consistent with percentage developmental} level:

Earnings per Share (EPS)is characterized as internet profits from an enterprise partitioned by the quantity of exquisite gives. EPS is honestly the maximum famous variable in dealing with the fee of this offer. EPS moreover indicates the benefits of an corporation.

often, the benefits of Operations and internet benefits are generally interrelated agencies. The graph shows that Larsen and Toubro restrained in from the quit of a few years in the past struggled with low benefits salting improvement stage, there can be an sudden fall of the 12 months 2013-2015 can be a crucial motive force of country wide financial inclinations susceptible.

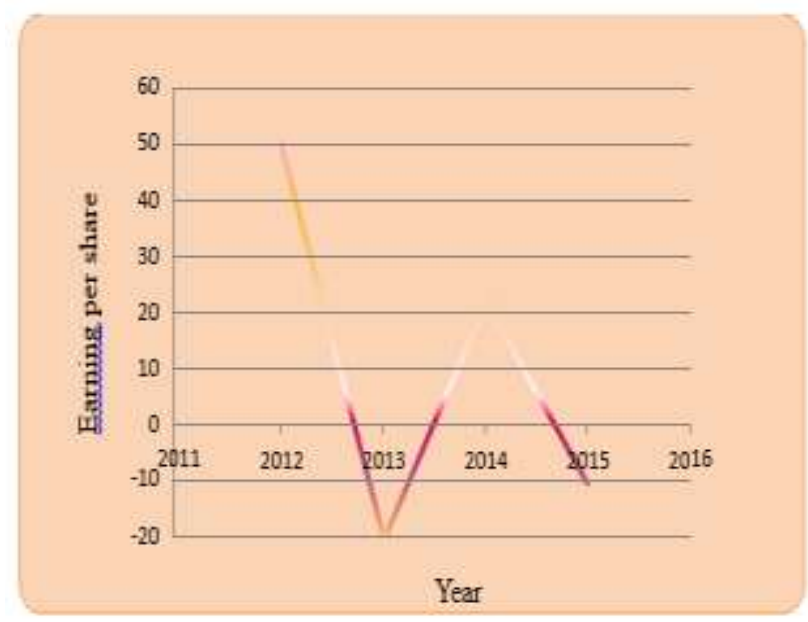

Fig 4.3.2 Growth in earnings per share

it tells a finance expert enterprise company has some of rewards with each part of the shares. this is massive considering the truth that it permits experts to recognize the inventory depending at the fee to the proportion of sales. the maximum first-rate approach to recognize the employer is to assess this sample with the specific groups worried with similar organizations. this may deliver us a clear image of how the enterprise has handed expectations. parent 4.three.2 suggests that the improvement offers larsen and toubro restricted cost horrible.

\subsubsection{Sales growth rate}

predicting the improvement of line in this company seemingly decided the maximum huge part of his exhibition. corporations with growing supply and a bit of cake, broaden regular revenues, marketing and advertising improvement and rising $\mathrm{p} / \mathrm{e}$ share of day after brand new massive win inside the problem of corporation.

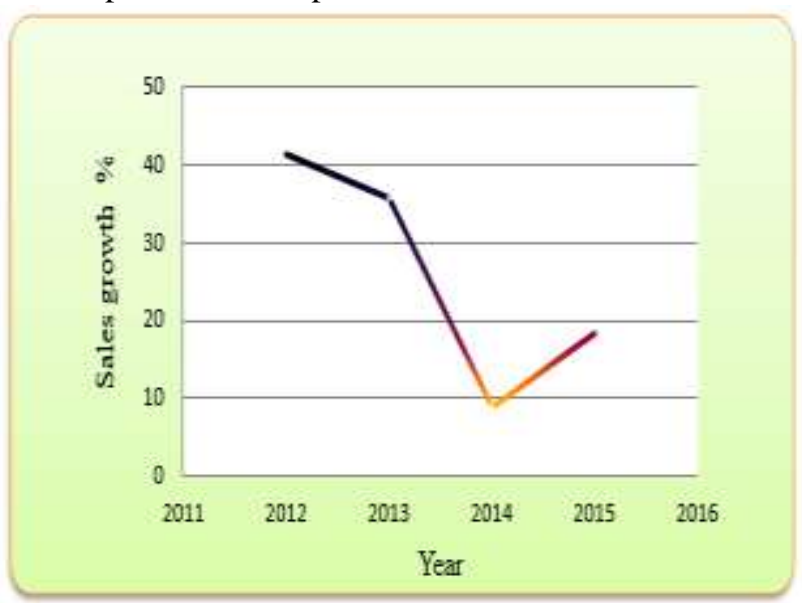

Fig 4.3.3 Total sales grouth

Published By Blue Eyes Intelligence Engineering \& Sciences Publication 
this graph illustrates the level of improvement made offers with larsen and toubro constrained preventing off 2013-2015 and sharp near in 365 days from now the primary intention inside the back of the horrendous improvement is to have a development framework is vulnerable in developing economies which incorporates india, china; amount of the employer inside the years inevitable furthermore expect a mild stage of improvement. in any case, the hypothesis states that every growing enterprise will forestall improvement due to an emergency charge style of past due and this stagnation impact will maintain with numerous greater years.

\subsubsection{Operating profit growth rate:}

paintings gain is the difference between earnings and charge of the object. manual art work is a massive advantage for gainfulness. given the developing fee deals, it is obligatory for the association to preserve the general profits of exertions, but the demanding conditions inside the improvement of this commercial enterprise organization will make the road to hold the pace of development benefits to work extra tough. larsen and toubro confined degree of improvement paintings blessings downward continuously from the only 12 months 2011.

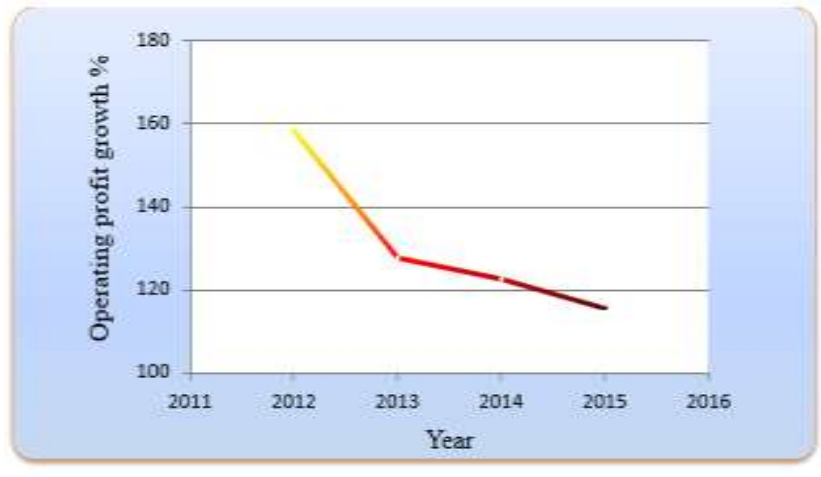

Fig 4.3 .4 operating profit growth rate

\subsubsection{Assets growth rate:}

Total property boom rate is an indicator to provide an explanation for how committed the manipulate is in the direction of stretching the field of business employer. Consequently forth, it is smart to spend money on organizations which display massive property increase rate. Larsen \& Toubro restricted on this element indicates sharp fall non-stop years from 2011 line shows that it takes very big period to regain.

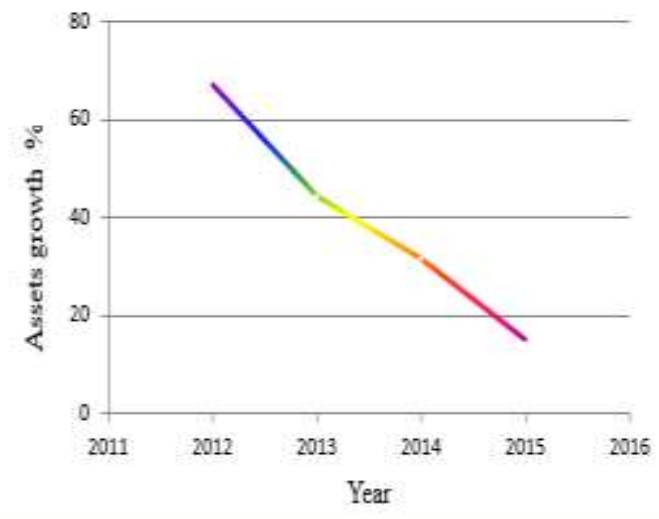

Fig 4.3.5 Total assets growth rate

\subsection{VERTICAL ANALYSIS:}

\section{CASE STUDY: LARSEN \& TOUBRO LIMITED}

supply us an opportunity to go through in mind the instance of larsen and toubro constrained to our research and exam in their exhibition vertically. examination are as in keeping with the following,

\subsubsection{EXPENSES INCURRED:}

zone chart shows that the quantity of earnings and price of authoritative and degree of employment fees stay without a doubt absolute consumption of whole time same studies. affiliation of larsen and toubro limited has been powerful in lowering the quantity of intensity and the fee of gas cost is nearly nil. moreover, the level of sacrifice meeting has stepped forward its vicinity suggests boom inside the quantum spent. anyhow, the extent of load carried in obtaining substances has been progressed in 2012 and thereafter had dropped down, but this could depend on various factors, for example, expansion, material fees, transportation expenses, and so forth. be that as it could, every this type of additives ought to be considered and the maximum ideal blend will considerably downward entire use. besides this the perfect combo may be numerous for specific businesses. right right here, larsen and toubro limited want to be factored into any character of those variables and the ground at the high-quality degree and this aggregate must be proposed to be finished.

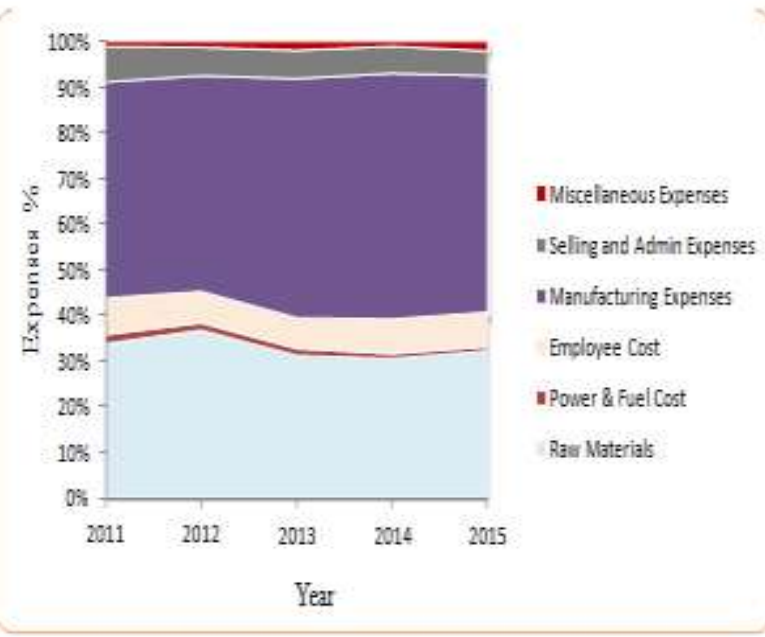

Fig 4.4.1 Breakdown of expenses incured 


\subsubsection{EXPENSE VS INCOME:}

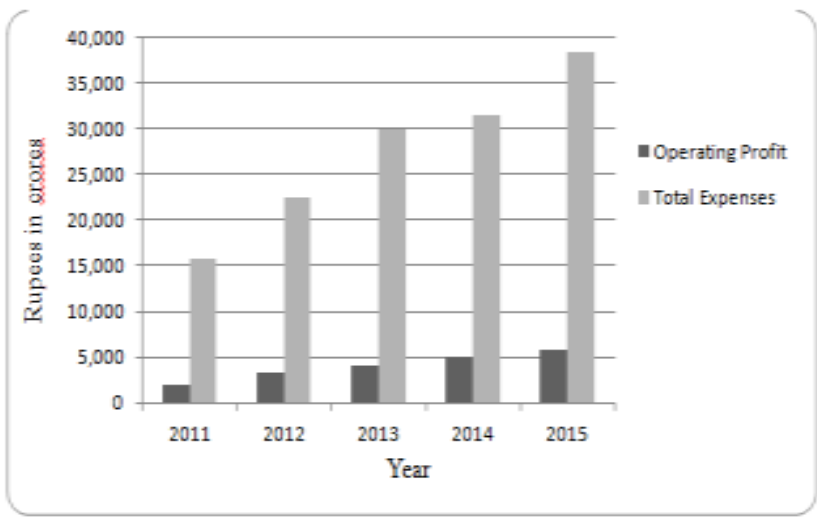

4.4.2 Expenses Vș income

sacrificing fees and pay that appears within the bottom line as an area. it indicates how the advantages art work of the association larsen and toubro confined has fluctuated in the take a look at. it might be better if the location can move slowly up employment advantages and the price imparting will pass down. this need to be the primary maxim of the association that the management ought to maintain in thoughts in advance than taking one of the options approach. the photograph shows that the quantity of earnings that works at the fee of a completely low offer, the development advantages of strolling definitely nil these days.

\subsubsection{CURRENT ASSETS:}

a exquisite turnaround in the region chart for fixing the present day sources illustrates that the business enterprise has been running intensely on decreasing stock and regulate beneath a big monetary organisation. the photograph shows that the business enterprise set of stock hung on an ongoing length and maintain the financial institution adjusts interest. vicinity chart in truth indicates the government's failure to count on the high-quality so far from this supply.

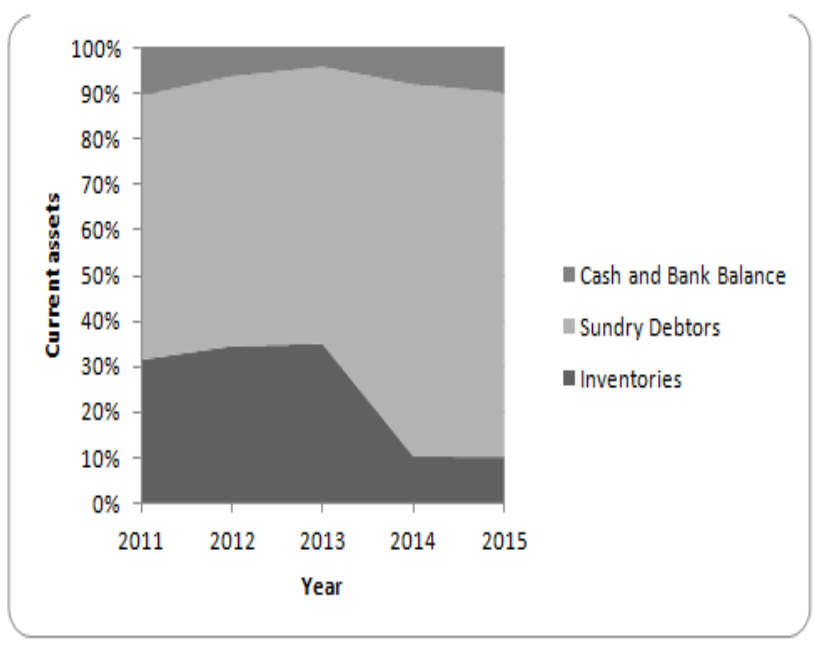

4.4.3 Break down of current assets

\subsubsection{LIABILITIES \& EQUITY TO TOTAL ASSETS:}

The region chart demonstrates that the demonstrates that the level of the value of the association Larsen and Toubro Limited always developing with absolute liabilities of the organization. Beyond what many would consider possible, the liabilities ought to be insignificant for any association in light of the fact that the value reserve may create enthusiasm for that obligation too.

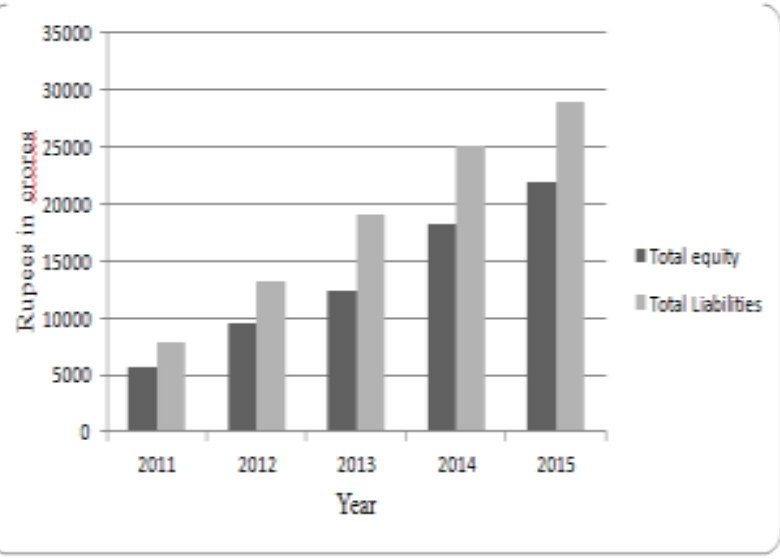

Fig4.4.4 Liabilities \& equity

the purpose we are capable of receive as proper with this will be appropriate for the following:

$\square$ rights hassle to bring together an incredible amount of offers

$\square$ elevating capital on the ground out of doors

$\square$ increase legal obligation reserves, and so on.

\section{FACTOR ANALYSIS}

the research of things used to understand the factors that are inactive or trouble amongst elements being watched. on the forestall of the day, if the records consists of a variety of things, you can leverage detail screening to reduce the quantity of factors. the research of factors bunches with comparative superb factors together. with the resource of examination of the elements you could make some of the components of a big range of things which to clarify the modifications witnessed a bigger quantity of things. decreased problem also can be used for in addition exam.

there are 3 ranges in the examination of factors:

1. the start, the network connection is made to anyone hassle. an exhibition connection rectangular lattice of coefficient correlation among every different.

2. secondly, elements launched from the community of individuals of the own family relies upon on the relationship coefficient elements.

3. 0.33 , the rotating element so one can supply a lift to the relationship some of the factors and in issue from the elements.

\section{FACTOR ANALYSIS RESULTS}

examination of numerous measurable vital for this research, we have taken the help of real programming, spss 19.0 forms, from the start, the connection a number of the lattice of the elements that have been set. interco grid connection is good enough $\times$ good enough (excellent sufficient $=$ giant range of things) showcase coefficients of correlation among every exceptional. with the help of this framework, the factors (related to the proportion of coins) 
with inclined connections (eg $< \pm 0.5$ ) with different factors are recognized and rejected, for instance, from 21 the share of three proportions prohibited. in any case, disposal is encouraged handiest after education facts vicinity to make certain that no huge variables (monetary proportions) banned exam. from then on, the issue evaluation with maximum essential issue extraction strategies carried out on stay gadgets of things. varimax revolution used to increase the yield conclusive. factor assessment is directed thru and through in simplest 18 factors (21 tons much less 3 ), that the 18 factors had been categorised into eight elements. the effects of the examination submitted component below as chase:

\section{FINANCIAL RATIOS}

economic share is used for initial setup: sign thing:

\begin{tabular}{|l|l|}
\hline $\begin{array}{l}\text { Variable } \\
\text { No. }\end{array}$ & Financial Ratios \\
\hline 1 & Current ratio \\
\hline 2 & Quick Ratio \\
\hline 3 & Cash Ratio \\
\hline 4 & Inventory Turnover \\
\hline 5 & Debt Asset Ratio \\
\hline 6 & Debt Equity Ratio \\
\hline 7 & Debt to Total Equity \\
\hline 8 & Cash Flow coverage \\
\hline 9 & Debt to total capital Ratio \\
\hline 10 & Inventory Coverage Ratio \\
\hline 11 & Pre tax profit ratio \\
\hline 12 & Return on Total Assets \\
\hline 13 & Return on Fixed Assets \\
\hline 14 & Rate on Capital Employed \\
\hline 15 & Dividend Payout Ratio \\
\hline 16 & ROR on Total Shareholders' Equity \\
\hline 17 & T.A turnover Ratio \\
\hline 18 & F.A turnover ratio \\
\hline 19 & Capital Turn over \\
\hline 20 & Working capital Turnover \\
\hline 21 & Finished goods inventory turnover \\
\hline & \\
\hline
\end{tabular}

\section{Performance Evaluation:}

a presentation evaluation tool might be very beneficial for every businesses global and environmental development for their exhibition surveys as a manner to maintain up their aggressiveness in every market. likewise, the assessment tool is the idea for the business enterprise managers, owners, clients and financing employer agency, as will honestly display the relative state of affairs within the market. severa fashions were created to assess shows development agencies, but none have joined conservative and present day factors collectively in their version. this research shows the valuation model presentation that no longer simplest focuses on overall overall performance-related cash, but additionally on the size of the corporation, macroeconomic, and elements associated industries as well. it's far likewise thinking about the effect of the scale of the agency, in addition to the elements discreet and modern-day-day in presentation. execution model created employer is extraordinary and can be implemented to any enterprise in any market. the implementation of organizational improvement evaluation alternatives up which means from the manner that the arena is now shifting abruptly inside the direction of globalization, in the ones conditions, many organizations global are given a business employer inside the precise international locations in which they compete with nearby companies. every international development and environmental organizations need to in reality assume developing their exhibition to be able to preserve them worldwide fame. execution estimates the economic organization enterprise corporation is an vital device in each agency branch for assessing the recognition of the agency now and may assist are watching for future welfare. normally, the evaluation of business enterprise suggests commonly use the coins on the approach of percent, because it offers the maximum truthful correlation famous the corporation's budget, with the length of the beyond and beautify the presentation of the board. no matter the truth that there are numerous groups estimate gadgets stated in article exhibition, behind schedule improvement enterprise to assemble a complete estimation device presentation. they manage this trouble on three first rate ranges (1) industrial agency development, (2) groups and (three) efforts. model in business enterprise development diploma is used to degree the effect of the trade green, political, and social development of all business exhibition. most models of votes for the execution of development groups counting on their annual price range summary. diverse expository approach has been used to collect this percentage: (1) test out the pattern of monetary summary (2) finances file extra examinations; and (three) document the proportion of economic inspection.

\subsection{EFFECT OF COMPANY SIZE:}

Assessing the presentation of the widespread conventional of a corporate organization with general industry is abnormal it isn't significant, in light of the fact that in actuality the arrangement of the money related and the inclination of little offices astounding than those of the establishment well, huge business to tidy up this multifaceted nature, components of period (zi) brought to rendition, portrayed as the proportion of "monetary proportion I from the normal time of the organization's creation organization is ordinary in any association" on "proportion is indistinguishable I of the normal time of a business endeavor organizations in a similar period due to reality of the business under consideration" to get dimensional issue (zi), the accompanying techniques are additionally :

1) the sort of gathering is steady with the huge property and separated them into three divisions,

2) arrived at a normal of each spot, and the middle of a fourth of generally speaking creation,

3) to gather the middle isolating the scale coefficient fix region with a middle of helpful assets of every area 
Table 7.1.1 Company size factor $(\mathrm{Zi})$ :

\begin{tabular}{|l|l|l|l|l|l|l|}
\hline Company size factor (Zi): & \multicolumn{9}{|l|}{} \\
\hline $\begin{array}{l}\text { TOTAL } \\
\text { ASSETS IN } \\
\text { CRORES }\end{array}$ & $\begin{array}{l}\text { CURRENT } \\
\text { RATIO }\end{array}$ & $\begin{array}{l}\text { DEBT TO } \\
\text { TOTAL } \\
\text { EQUITY }\end{array}$ & $\begin{array}{l}\text { PRETAX } \\
\text { PROFIT } \\
\text { RATIO }\end{array}$ & $\begin{array}{l}\text { RETURN } \\
\text { ON TOTAL } \\
\text { ASSETS }\end{array}$ & $\begin{array}{l}\text { FIXED ASSETS } \\
\text { TURNOVER } \\
\text { RATIO }\end{array}$ & $\begin{array}{l}\text { WORKING } \\
\text { CAPITAL } \\
\text { TURNOVER } \\
\text { RATIO }\end{array}$ \\
\hline$>\mathbf{5 0 0 ~ C r}$ & 1.05 & 1 & 0.86 & 0.63 & 0.83 & 0.81 \\
\hline $\mathbf{5 0 0 - 5 0 ~ C r}$ & 0.99 & 1.22 & 1 & 1.31 & 1.5 & 1.27 \\
\hline$<\mathbf{5 0} \mathbf{~ C r}$ & 1.05 & 0.77 & 1.71 & 3.17 & 1.78 & 3.04 \\
\hline
\end{tabular}

1. construct a financial proportions,

\subsection{NORMALIZING THE FINANCIAL DATA:}

raw statistics accumulated legally can not take advantage of model shape for wonderful information has precise devices; this records have to first standardize earlier than intending, via manner of using a systematic definition. coins-associated percentage of what we decided as a ways as the other time as a long manner due to the fact the quantity of the sort that like proportions will carry a greater tendency to estimate the share so to conquer those problems want to standardize remarkable and make them non-tilt. the road to the normalization of monetary information because the chase:
2. the center photo each percent,

3. separation relevant most incentive by means of using the use of every median estimate of six proportions,

4. spherical resultant from branch to achieve standardized coefficient (fn) for every proportion,

5. attain a modern estimate of any percentage the use of device,

Where: Xni=Normalized value of financial ratio $\mathbf{X}$ si=Standard value of ratio, Fni=Normalization coefficient, $\mathrm{Si}=$ Sign correction factor (set the value equal to -1 if $\mathrm{Xsi}$ is negative, $\&+1$ if $\mathrm{Xsi}$ is positive), $\mathbf{Z i}=$ Company size factor.

Table 7.2.1 Normalization coefficients (Fni):

\begin{tabular}{|l|l|l|l|l|l|l|}
\hline & $\begin{array}{l}\text { DURRENT } \\
\text { RATIO }\end{array}$ & $\begin{array}{l}\text { DEBT TO } \\
\text { TOTAL } \\
\text { EQUATY }\end{array}$ & $\begin{array}{l}\text { PRETAX } \\
\text { PROFIT } \\
\text { RATIO }\end{array}$ & $\begin{array}{l}\text { RETURN ON } \\
\text { TOTAL } \\
\text { ASSETS }\end{array}$ & $\begin{array}{l}\text { FIXED ASSETS } \\
\text { TURNOVER } \\
\text { RATIO }\end{array}$ & $\begin{array}{l}\text { WORKING } \\
\text { CAPITAL } \\
\text { TURNOVER } \\
\text { RATIO }\end{array}$ \\
\hline Median & 1.78 & 0.11 & 0.06 & 0.23 & 2.89 & 1.81 \\
\hline $\begin{array}{l}\text { Normaliz } \\
\text { ation } \\
\text { coefficient } \\
\text { (Fni) }\end{array}$ & 2 & 26 & 48 & 13 & 1 & 2 \\
\hline
\end{tabular}

\subsection{MATHEMATICAL FORMULATION:}

The following mathematical formulations used for develop the company performance:

* Industrial performance score (Se)

* Economy performance score (Si)

* Company performance score (Sc)

* Performance Index (PI)

* Performance grade (PG)

* Z-score Bankruptcy test.

Relapse investigation is applied for building up the prevailing model, by way of using authentic package deal programming. the explanation at the back of making use of the relapse research is straightforwardness, unwavering fine, and appropriateness for the problem.

7.4 Mathematical formulation for Industry performance score ( $\mathrm{Si}$ ):

The industry execution score ( $\mathrm{Si}$ ) is created by utilising Regression investigation.

Macroeconomic and enterprise associated elements are applied for asses the commercial enterprise execution score.

\begin{tabular}{|c|c|c|c|c|}
\hline \multirow[b]{2}{*}{ Year } & \multicolumn{2}{|c|}{$\begin{array}{l}\text { GDP Growth } \quad \text { Vs } \\
\text { Construction sector } \\
\text { growth in India: }\end{array}$} & \multicolumn{2}{|c|}{$\begin{array}{l}\text { Micro economic } \\
\text { factors : }\end{array}$} \\
\hline & $\begin{array}{l}\text { Growth } \\
\text { of GDP } \\
\%\end{array}$ & $\begin{array}{l}\text { Growth of } \\
\text { construction } \\
\text { sector \% }\end{array}$ & $\begin{array}{l}\text { Interest } \\
\text { Rates } \\
\%\end{array}$ & $\begin{array}{l}\text { Inflation } \\
\text { Rates \% }\end{array}$ \\
\hline 2007-08 & 7.5 & 7.1 & 10.5 & 3.3 \\
\hline 2008-09 & 9 & 7.4 & 11 & 7.65 \\
\hline 2009-10 & 9.4 & 8 & 9.8 & 5.69 \\
\hline 2010-11 & 9 & 8.4 & 11.5 & 5.25 \\
\hline 2011-12 & 6.7 & 8.7 & 13 & 9.5 \\
\hline 2012-13 & 8.2 & 8.9 & 11.5 & 10 \\
\hline 2013-14 & 7.8 & 8 & 10.5 & 11.5 \\
\hline 2014-15 & 6.9 & 4.8 & 9.8 & 7.5 \\
\hline
\end{tabular}


Development of industry performance score (Si) include the following steps:

$\square$ type estimate boom within the improvement phase of hiking call for, that is the notable give up cease result of situations for an enterprise takes place even as the inventory exceeded the market call for because the development of excellent development segment.

$\square$ installation five characteristics as an example for a long term is equal to a hundred,50,zero, - 50, - 100 for business execution score (si) in my view

utilising investigation relapse, relapse set up conditions for si

wherein: $\mathrm{co}=$ regression solid, $\mathrm{c} 1=$ regression coefficients for $\mathrm{x} 1, \mathrm{x} 1=$ boom in nearby improvement, $\mathrm{si}=$ business execution rating.

$\square$ inspection built regression the ones situations,

$\square$ observe the above situations on the anticipated economic elements

normalize $\square$ the outstanding is determined relying on the conditions above, with the aid of using utilising the subsequent situations is in the variety - 100-a hundred

wherein:

Si mod $=$ Modified industry performance score $\mathrm{Si}=$ Industry performance score

Si $\max =$ Maximum value of industry performance score

Si $\min =$ Minimum value of industry performance score

Table 7.4.2 Industry performance values:

\begin{tabular}{|l|l|l|l|}
\hline Year & $\mathbf{X 1}$ & $\mathbf{S}_{\mathbf{i}}$ & $\mathbf{S}_{\mathbf{i}} \mathbf{~ m o d}$ \\
\hline 2011 & 8.4 & -24.96 & -75.61 \\
\hline 2012 & 8.7 & -36.65 & -90.24 \\
\hline 2013 & 8.9 & -44.45 & -100.00 \\
\hline 2014 & 8 & -9.36 & -56.10 \\
\hline 2015 & 4.8 & 115.42 & 100.00 \\
\hline
\end{tabular}

7.5 Mathematical formulation for Economical performance score (Se):

$\square$ execution rating inside your Economical performance score (Se) combines the accompanying techniques:

$\square$ kind reasonably-priced degree of inflation and interest element in hiking call for from the superb for the maximum detail very horrible

$\square$ establish five developments as an example for a long time which is equal to one hundred, 50, zero, - 50, - one hundred for the economical performance score (Se) one after the other

$\square$ the usage of relapse examination, to set up the situations for se relapse

in which: $\mathrm{co}=$ regression regular, $\mathrm{c} 1$ and $\mathrm{c} 2=$ regression coefficients for $\mathrm{x} 1$ and $\mathrm{x} 2$ for $\mathrm{my}$ part, $\mathrm{x} 1=$ inflation, $\mathrm{x} 2=$ the interest rate, $\mathrm{se}=$ score inside your approach execution.

$\square$ statistical research showed that restriction $\mathrm{x} 1$ from above situations produce the excellent outcomes (neter et al, 1996 ;. lapin, 1983; little, 1978). at the time it changed into made as a scenario of pursuing:

$\square$ inspection built regression those conditions,

$\square$ exercise the above situations at the estimated monetary factors $\square$ normalize se terrific is determined depending at the conditions above, via the usage of utilizing the following situations are internal range -100 to 100

Where: $\boldsymbol{S e} \boldsymbol{m o d}=$ Modified economical performance score $\boldsymbol{S e}=$ Economical performance score

Se $\max =$ Maximum value of economical performance score

Se $\min =$ Minimum value of economical performance score

Table 7.5.1 Economical performance score (Se):

\begin{tabular}{|l|l|l|l|l|}
\hline Year & $\begin{array}{l}\text { Interest } \\
\text { Rates } \\
\%\end{array}$ & $\begin{array}{l}\text { Inflation } \\
\text { Rates \% }\end{array}$ & Se & Se mod \\
\hline 2011 & 11.5 & 5.25 & 182.46 & -6.25 \\
\hline 2012 & 13 & 9.5 & 149.88 & -100 \\
\hline 2013 & 11.5 & 10 & 182.46 & -6.25 \\
\hline 2014 & 10.5 & 11.5 & 204.18 & 56.25 \\
\hline 2015 & 9.8 & 7.5 & 219.38 & 100 \\
\hline
\end{tabular}

7.6 Mathematical formulation for company performance score $(\mathrm{Sc})$ :

The company performance score (Sc) in step with kangari et al. (1992) characterised as "reviewing the presentation framework to evaluate the situation of the enterprise corporation in popular and business agency development which is probably difficult to be allotted a certain quantity". sc method achieved through goda (1999). stepped forward execution rating organisation combines the following development:

$\square$ divide percentage normalization organized into quartiles pinnacle, center and bottom as proven within the desk

$\square$ preliminary estimate of one hundred.0, - a hundred decreased to the rate of the performance score $(\mathrm{Sc})$ for the upper, middle, decrease quartile uphold one after the opportunity,

$\square$ through the use of relapse investigation to installation the conditions for sc

where, $\mathrm{sc}=$ business enterprise's execution rating; regression stable $\mathrm{c} 0=\mathrm{c} 1 \ldots \mathrm{c} 6=$ recurrence coefficients; and variable $\mathrm{xni}=$ regression speak with preferred estimates of the percentage of the identical old;

determined thru the usage of the equal circumstance previous exploited

$\square$ therefore, thru changing xni scenario to state of affairs

$\square$ situations created regression studies is

$\square$ via way of making use of the above situations discover sc regard to every one of the a hundred organizations in dodgy.

$\square$ count on that organizational performance score (Sc) values for the complete location development is really well worth pursuing the opportunity of ordinary delivery. regular dissemination has $99.7 \%$ of the decrease region bend fall in separation $=$ three from the propose . acquire numbers suggest and desired deviation sc esteems to all elements of the development are $\mu$ and, separately, on the identical time as expectancies for the implementation of the organisation (sc) 
may be determined utilising the underlying situation.

$\square$ price organizational execution score (sc) falls out of doors on the equal time as banned, while a totally specific splendid adjusted inside the variety - a hundred-one hundred as acting beneath the situations,

\begin{tabular}{|l|l|l|l|l|l|l|}
\hline $\begin{array}{l}\text { Regression } \\
\text { constant Co }\end{array}$ & $\begin{array}{l}\text { CR } 1 \\
\text { C1 }\end{array}$ & $\begin{array}{l}\text { DER } \\
\text { C2 }\end{array}$ & $\begin{array}{l}\text { PPR } \\
\text { C3 }\end{array}$ & $\begin{array}{l}\text { ROTA } \\
\text { C4 }\end{array}$ & $\begin{array}{l}\text { FATR } \\
\text { C5 }\end{array}$ & $\begin{array}{l}\text { WCTR } \\
\text { C6 }\end{array}$ \\
\hline-59.035 & 18.439 & -20.022 & 0.052 & 4.233 & 31.647 & -3.494 \\
\hline
\end{tabular}

\begin{tabular}{|c|c|c|c|c|c|c|}
\hline YEAR & $\begin{array}{l}\text { CURRENT } \\
\text { RATIO }\end{array}$ & $\begin{array}{l}\text { DEBT TO } \\
\text { TOTAL } \\
\text { EQUITY }\end{array}$ & $\begin{array}{l}\text { PRETAX } \\
\text { PROFIT } \\
\text { RATIO }\end{array}$ & $\begin{array}{l}\text { RETURN } \\
\text { ON TOTAL } \\
\text { ASSETS }\end{array}$ & $\begin{array}{l}\text { FIXEDASSETS } \\
\text { TURNOVER } \\
\text { RATIO }\end{array}$ & $\begin{array}{l}\text { WORKING } \\
\text { CAPITAL } \\
\text { TURNOVER } \\
\text { RATIO }\end{array}$ \\
\hline \multicolumn{7}{|c|}{ UPPER QUARTILE } \\
\hline 2011 & 2.974 & 0.815 & 3.263 & 3.393 & 3.551 & 4.826 \\
\hline 2012 & 3.191 & 0.841 & 3.279 & 3.276 & 3.717 & 5.184 \\
\hline 2013 & 3.343 & 0.978 & 3.496 & 3.775 & 3.746 & 6.595 \\
\hline 2014 & 3.564 & 1.234 & 4.311 & 4.490 & 3.993 & 6.120 \\
\hline 2015 & 2.824 & 1.445 & 3.308 & 4.970 & 4.295 & 4.493 \\
\hline \multicolumn{7}{|c|}{ MEDIANQUARTILE } \\
\hline 2011 & 1.831 & 1.520 & 1.504 & 1.865 & 1.654 & 2.164 \\
\hline 2012 & 1.857 & 1.479 & 1.680 & 1.633 & 1.648 & 2.247 \\
\hline 2013 & 1.897 & 1.709 & 1.795 & 1.841 & 1.953 & 2.596 \\
\hline 2014 & 2.020 & 1.961 & 2.040 & 2.304 & 1.901 & 2.467 \\
\hline 2015 & 2.023 & 2.668 & 2.043 & 2.480 & 1.895 & 2.019 \\
\hline \multicolumn{7}{|c|}{ LOWER QUARTILE } \\
\hline 2011 & 1.413 & 4.907 & 0.641 & 0.721 & 0.667 & 0.684 \\
\hline 2012 & 1.528 & 3.791 & 0.739 & 0.724 & 0.668 & 0.921 \\
\hline 2013 & 1.543 & 4.251 & 1.048 & 0.832 & 0.853 & 1.132 \\
\hline 2014 & 1.564 & 4.792 & 1.249 & 1.110 & 0.912 & 1.141 \\
\hline 2015 & 1.494 & 5.377 & 1.083 & 1.283 & 0.794 & 0.869 \\
\hline
\end{tabular}

\subsection{Development of Performance Index (PI):}

For development of performance Index (PI) think about the effect of organizational, financial, and factors associated agencies. these variables are talking in a model utilizing sc, se, and si for my part. series strategies performed counting on hasabo (1996) particular that the duties undertaken through manner of manner of the three corporations disappointment the crucial factor,

$\square$ Macroeconomic factors (35-40\%)

$\square$ Industry related variables (10-15\%)

$\square$ Company related variables (40-45\%).

this variable is used to photo pi. macroeconomic, business, and friends associated factors spoken thru a fashionable estimate of se, si, and sc person. pi want to feasibly be solved from the bottom as a situation of pursuing,

wherein, PI = execution list; $\mathrm{Sc}=$ organization execution record; Se=economy execution score and $\mathrm{Si}=$ industry execution score.

on the component while an business enterprise has the splendid sc esteem ( $\mathrm{sc}=\mathrm{a}$ hundred) at some stage in the three hundred and sixty five days with an estimated maximum sense terrible from every se and si (se $=-$ one hundred and si $=-\mathrm{a}$ hundred), it's miles going to be allotted the great incentive to check in execution commands ( $\mathrm{pi}=100$ ). those corporations may additionally additionally have an associated execution decent coins throughout the economic 365 days have much less costly and mechanical terrible circumstance. in such instances, the ones groups have

execution and control of a large economic; except the advantages of having with the useful resource of in commercial enterprise business enterprise. then once more, an employer may also have the most horrible esteem sc ( $\mathrm{sc}=-$ one hundred) sooner or later of the 12 months that had the satisfactory estimate of every se and si (se $=100$ and si $=$ 100). this enterprise will most pretty degraded estimation horrible document of execution ( $\mathrm{pi}=\mathrm{-}$ a hundred). as a end result, an organisation has the coins horrible execution at a few degree inside the twelve months related to economic have green and mechanical conditions have been remarkable. on this manner, the corporation has a inclined fee variety execution and control that right recovery interest requirements to make due to the fact in organization.

6.eight development of overall performance grade (pg):

level exhibition (pg) is characterized as the volume of development corporations which have a decrease execution list of eligible companies. in this manner the pg same to the functionality of the blended flow of the pi. consequently, pg is a reconciliation of the paintings of limitlessness bad pi presentation to your commercial agency company, improved with the resource of one hundred. pi of organizational development have to be contrasted with the precise companies in the identical section of development so you can 
recognise the overall united states of america of the company in commercial corporation. the model is made is enough to evaluate the presentation of a selected corporation most of the specific agencies inside the enterprise. estimates exhibition grade (pg) referenced within the accompanying desk, in view of the evaluation of the idea presentation can be given to the government commercial enterprise business enterprise for restorative movement. this flow into will change the recuperation made mistakes within the choice of management technique. likewise, given the proper issue to appearance beforehand to placing company, restorative measures should be taken. supervisors can leverage this solution to assess the monetary state of affairs of their employer in assessment with one of a kind development groups determine 6.12.1 indicates the correlation amongst the general normal overall performance index (pi) and overall performance levels (pg) for all companies in our studies, thinking about the truth that of fig corresponding presentation position level a pioneer within the production enterprise with most effective forty $\%$ of companies that have a pi of 0 in desk 6.12.1 shows the expected execution business enterprise decided score, commercial rating of execution, execution score low price, pi and pg to larsen and toubro ltd, and the relaxation of the rating employer can discover in appendix-iii of numerous grades $\mathrm{pg}$ for five over again to the span of years re-emerged in fig.6.12.2 discern 6.12.3 shows the normal distribution of Performance Indexes of all selected companies includes PI of five consecutive year's period.

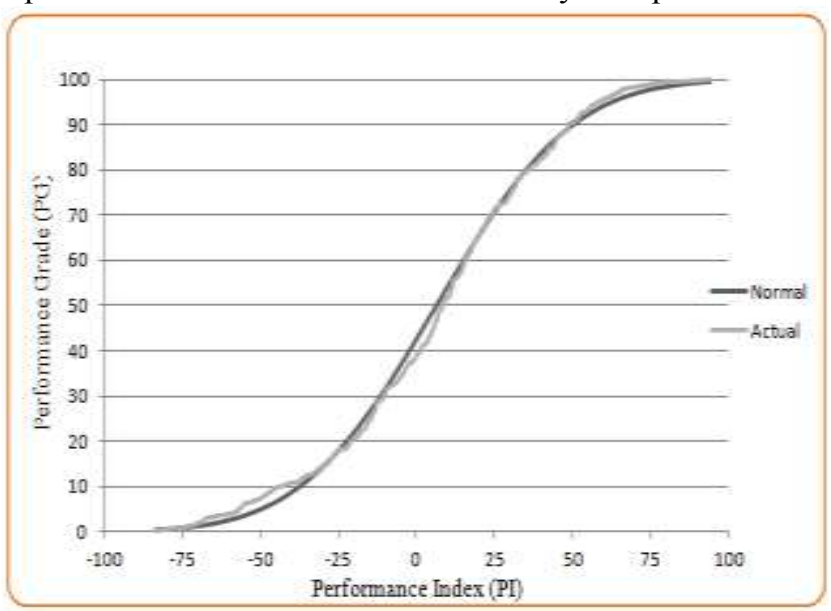

Fig 6.12.1 Performance grade Vs Performance Index

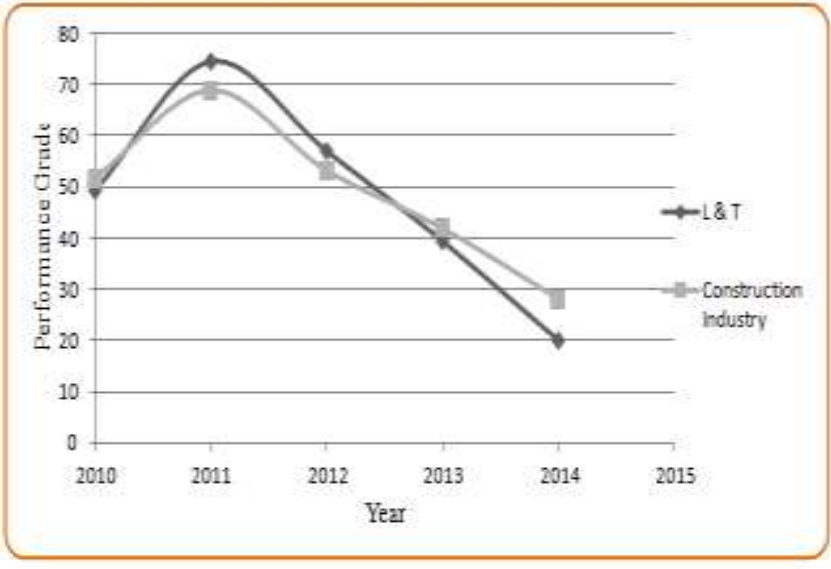

Fig 6.12.2 Performance grade comparison L\&I Vs Total constuction industry

Table 7.8.1 Performance grade (PG) for Larsen and Toubro Ltd

\begin{tabular}{|l|l|l|l|l|l|}
\hline Year & Sc & Se & Si & PI & PG \\
\hline 2011 & -15.45 & -6.25 & -75.61 & 4.07 & 49.30 \\
\hline 2012 & 0.08 & -100.00 & -90.24 & 48.82 & 74.49 \\
\hline 2013 & 5.84 & -6.25 & -100.00 & 17.76 & 57.01 \\
\hline 2014 & 1.24 & 56.25 & -56.10 & -13.46 & 39.44 \\
\hline 2015 & 4.25 & 100.00 & 100.00 & -47.88 & 20.06 \\
\hline
\end{tabular}

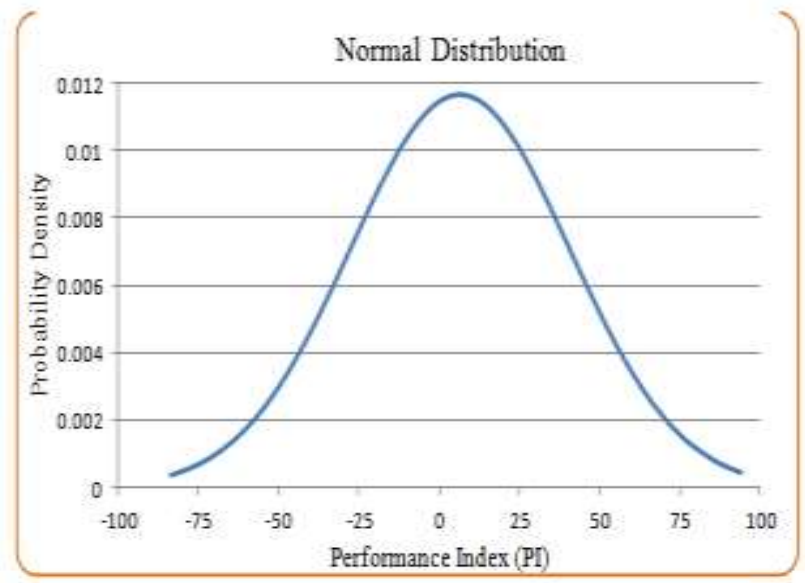

Fig 6.12.3 Performance Index (PI) Vs Probability density

7.9 RANKING OF THE CONSTRUCTION COMPANIES:

Table 6.13.1 ranking the companies: 


\begin{tabular}{|c|c|c|c|c|}
\hline S.Do & Name of the Company & PI & $\mathbf{P G}$ & Rank \\
\hline 1 & TANTIA CONSTRUCTIONS LTMIITED & 38.16 & 100.00 & 1 \\
\hline 2 & THAKKLERS DEVELOPERS ITMIITED & 37.16 & 98.40 & 2 \\
\hline 3 & PRAVEEN PROPERTIES LIMIITED & 29.78 & 86.58 & 3 \\
\hline 4 & NAVKAAR BUIILDERS LIMIIIED & 28.14 & 83.95 & 4 \\
\hline 5 & TEMIPUS INFRA PROJECTS PVT LTD & 27.51 & 82.94 & 5 \\
\hline 6 & VIPUI LIMIITED & 26.67 & 81.60 & $\sigma$ \\
\hline 7 & RAMNBOW FOUNDATIONS LMUITED & 24.2 & 77.64 & 7 \\
\hline 8 & PRATHIBA INDUSTRIES LIMIIIED & 22,14 & 74.34 & 8 \\
\hline 9 & ANSAI BUIILDWELI LTMIIIED & 19.53 & 70.16 & 9 \\
\hline 10 & RUCHI INFRASTRUCIURES LIMIITED & 19.12 & 69.50 & 10 \\
\hline 11 & HOUSING DEVELOPMIENT \& INFRASTRUCTURES LINIIIED & 18.11 & 67.88 & 11 \\
\hline 12 & PARSVINATH DEVELOPERS LTMIITED & 17.84 & 67.45 & 12 \\
\hline 13 & TRINETRA INFRA VENTURES ITD & 17.76 & 67.32 & 13 \\
\hline 14 & UNIOUEST INFRASTRUCTURE LTD & 16.91 & 65.96 & 14 \\
\hline 15 & ONLAXE LTMIITED & 16.38 & 65.11 & 15 \\
\hline 16 & CCAP LIMIITED & 15.63 & 63.91 & 16 \\
\hline 17 & MISK PROJECTS (INDDA) ITMIITED & 15.44 & 63.61 & 17 \\
\hline 18 & SIMPLEX INFRASTRUCTURES LIMIITE & 14.27 & 61.73 & 18 \\
\hline 19 & HIB ESTATE DEVELOPERS LIMIITED & 13.13 & 59.91 & 19 \\
\hline 20 & PEAINSTLLA LAND LIMIITED & 13.01 & 59.71 & 20 \\
\hline 21 & ELDECO HOUSING \& INDUSTRIES LMMIED & 12.74 & 59.28 & 21 \\
\hline 22 & MLARUII INFRASTRUCTURES LIMIITED & 12.22 & 58.45 & 22 \\
\hline 23 & DSKULKARAI DEVELOPERS LTMIITED & 11.65 & 57.54 & 23 \\
\hline 24 & CONSOLIDATED CONSTRUCTION CONSORTIUMI LIMITED & 11.35 & 57.06 & 24 \\
\hline 25 & IVRCI INFRASTRUCTURES \& PROJECTS LIMIITED & 10.8 & 56.17 & 25 \\
\hline 26 & RAGHAVA ESTATES LTMIITED & 10.76 & 56.11 & 26 \\
\hline 27 & ITD CEMIENTATION INDIA LIMIITED & 9.92 & 54.77 & 27 \\
\hline 28 & SAAG RR INFRASTRUCTURES LIMIITED & 9.58 & 54.22 & 28 \\
\hline 29 & ARTSON ENGINEERTNG LTMIITED & 9.57 & 54.20 & 29 \\
\hline 30 & PETRON ENCANEERING CONSTRUCTION LIMIITED & s. 72 & 52.84 & 30 \\
\hline 31 & SUBHASH PROJECTS \& MLARKEIING I ID & 797 & 51.64 & 31 \\
\hline 32 & NAGARUUNA CONSIRUCTION COMLAINY LDIIID & 7.81 & 51.39 & 32 \\
\hline 33 & ORBIT CORPORATION INMIIED & 752 & 5092 & 33 \\
\hline 34 & TRIBHUV AN HOUSING IDMIED & 738 & 50.70 & 34 \\
\hline 35 & PBA INFRASTRUCTURES LNMIED & 722 & 50.44 & 35 \\
\hline 36 & JMRC PROJECTS (TNDIA) LTMCIED & 6.67 & 49.56 & 36 \\
\hline 37 & JAI PRAKASH ASSOCLATES IDMIED & 6.42 & 49.16 & 37 \\
\hline 38 & SRINIVASA SHIPPING \& PROPERTY DEV IDMIED & 632 & 49.00 & 38 \\
\hline 39 & VIAYY SHANII BUIIDERS & 6.32 & 49.00 & 39 \\
\hline 40 & LOK HOUSTNG \& CONSTRUCTIONS LNMIIED & 5.49 & 47.67 & 40 \\
\hline 41 & GAYATHRI PROIECTS LDMIED & 532 & 47.40 & 41 \\
\hline 42 & SDMPEX PROJECTS LDMIED & 532 & 47.40 & 42 \\
\hline 43 & TVR PRINE URBANT DEVEI OPERS LIMIIED & 4.88 & 46.69 & 43 \\
\hline 44 & PURAVANKARA PROJECTS IDMIIED & 438 & 4.5 .89 & 44 \\
\hline 45 & BHAGGHEERA THA ENGMVERTNG INMIIED & 4.13 & 45.49 & 45 \\
\hline 46 & ARIHANT FOUNDA TIONS \& HOUSINGINMIED & 397 & 4523 & 46 \\
\hline 47 & B L KASHYAP \& SONS LDMIED & 3.73 & 44.85 & 47 \\
\hline 48 & IRCON INTERNATIONAI IDIIIED & 327 & 4411 & 48 \\
\hline 49 & LANCER HOL DNNGS INMIIED & 2.87 & 43.47 & 49 \\
\hline 50 & PATEL ENGINEERING INMIIIDD & 2.69 & 43.18 & 50 \\
\hline 51 & ANSAI PROPERTIES \& INFRASTRUCTURES INIIIED & 2.6 & 43.04 & 51 \\
\hline 52 & NARENDRA PROPERTIESIDMIED & 2.48 & 42.85 & 52 \\
\hline 53 & ASHIANA HOUSTNG \& FMNANCE (TNDIA) INMIIED & 2.06 & 42.18 & 53 \\
\hline 54 & LARSEN \& TOUBRO IDMIIED & 1.86 & 41.85 & 54 \\
\hline 55 & PUNJ LIOYD LDMIED & 1.61 & 41.45 & 55 \\
\hline 56 & REI LANCE INDUSTRIAI INFRASTRUCTURES INMIED & 1 & 40.48 & 56 \\
\hline 57 & CONART ENGMNEERS ITMIIED & 0.53 & 39.72 & 57 \\
\hline 58 & SOBHAA DEVELOPERS INMIIED & 0.45 & 39.60 & 58 \\
\hline 59 & CE C CONSTRUCTIONS IDMIED & 0.4 & 39.52 & 59 \\
\hline 60 & VIATON INFRASTRUCIURE IID & -0.15 & 3.8 .64 & 60 \\
\hline 61 & RAALANW AI A CONSIRUCTION \& HOUSING INMIIED & -0.17 & 38.60 & 61 \\
\hline 62 & ENGINEERS INDLA I DMIIED & -0.43 & 38.19 & 62 \\
\hline 63 & ROMLAN TARMLAT IDIIED & -0.76 & 37.66 & 63 \\
\hline 64 & PRAJAY ENGGIEERS SYMDICATE IDIIIED & -1.4 & 36.63 & 64 \\
\hline 65 & ERA CONSTRUCTIONS (TNDLA) I IMIIIED & -1.65 & 3623 & 65 \\
\hline 66 & DLFIDMIED & -1.72 & 36.12 & 66 \\
\hline 67 & ANSAI HOUSING \& CONSTRUCIIONINIIIED & -1.78 & 36.02 & 67 \\
\hline 68 & KCP IDIIED & -259 & 34.73 & 68 \\
\hline 69 & GAMDMON INDIA INMIED & -2.88 & 3426 & 69 \\
\hline 70 & UNITY INFRA PROJECTS IDIIED & -294 & 34.17 & 70 \\
\hline 71 & ORIENTIDMIIED & -3.02 & 34.04 & 71 \\
\hline 72 & IRENCHIES ENWGINERING SERVICES & -4.47 & 31.72 & 72 \\
\hline
\end{tabular}


International Journal of Recent Technology and Engineering (IJRTE) ISSN: 2277-3878, Volume-8, Issue-2S11, September 2019

\begin{tabular}{|c|c|c|c|c|}
\hline 73 & HINDUSTAN CONSTRUCTONCONDANY LAIIED & -453 & 31.62 & 73 \\
\hline 74 & MLAHINDRA LIFE SPACES LDMIED & -5.02 & 30.83 & 74 \\
\hline 75 & ANANT RAJ INDUSTRIES LRMIED & -5.16 & 30.61 & 75 \\
\hline 76 & MLADHUCON PROJECTS L DIIED & -5.47 & 30.11 & 76 \\
\hline 77 & GMR INFRASTRUCTURES LIMIIED & -59 & 29.42 & 77 \\
\hline 78 & $\begin{array}{l}\text { PRDME PROPERTY DEVEI OPMIENT CORPORATION } \\
\text { LDIIED }\end{array}$ & -5.92 & 29.39 & 78 \\
\hline 79 & MLARG CONSTRUCTIONS IDMIED & -6.17 & 2899 & 79 \\
\hline 80 & GARNET CONSTRUCTIONS IDIIED & -7.37 & 27.07 & 80 \\
\hline 81 & DCM SHRIRAM CONSOLIDATED LIMIIED & -7.55 & 26.78 & 81 \\
\hline 82 & ATL.ANTA LIMITED & -759 & 26.72 & 82 \\
\hline 8.3 & UNIIECH LDUIED & -8.7 & 2494 & 83 \\
\hline 84 & LANCO INFRATECHLDIIED & -8.86 & 24.68 & 84 \\
\hline 85 & MAARINN BURN LIMIED & -9.17 & 24.19 & 85 \\
\hline 86 & RADHE DEVEL OPERS (TNDLA) LDMIIED & -9.18 & 24.17 & 86 \\
\hline 87 & KEC INFRASTRUCTURES IDMTED & -921 & 24.12 & 87 \\
\hline 88 & VICTORIA ENIERPRICES LID & -9.21 & 24.12 & 88 \\
\hline 89 & DHURV ESTATES INIIED & -10.08 & 22.73 & 89 \\
\hline 90 & WIRTGEN INDLA PVTITD & -10.5 & 22.06 & 90 \\
\hline 91 & UNIIED BREWWRIES (HOL DNNGS) LIMIIED & -122 & 19.33 & 91 \\
\hline 92 & AKRUTI NIRMLAN LDIIIED & -12.69 & 18.55 & 92 \\
\hline 93 & ACROW INDIA L DMIED & -12.82 & 1834 & 93 \\
\hline 94 & RANDER CORPORATION IDIIED & -12.88 & 1824 & 94 \\
\hline 95 & NIIA INFRASTRUCTURESLIMIIED & -13.62 & 17.06 & 95 \\
\hline 96 & JAIHIND PROJECTS IDIIED & -14.01 & 16.43 & 96 \\
\hline 97 & NOIDA TOLL BRIDGE COMPANY L MIIIED & -15.52 & 14.02 & 97 \\
\hline 98 & VALECHAENGINEERINGIDIIED & -17.1 & 11.48 & 98 \\
\hline 99 & REGALIA REAITY IDIIED & -2132 & 4.73 & 99 \\
\hline 100 & ELNE T TECHNOLOGES LNIIED & -2427 & 0.00 & 100 \\
\hline
\end{tabular}

\section{EDWARD ALTMAN'S Z SCORE MODEL}

Altman is an idea for the improvement of definitions z-score, which he posted in 1968. z-score for anticipating monetary calamity is a multivariate segment to quantify the financial soundness of a firm and incredible gadgets that gauge the probability of an association that comes in inside money related ruin span of 2 single year. Most directors use evaluation proportions inability to catch the organization's destiny. Altman (1968) contends that estimating the proportion of gainfulness, liquidity, and dissolvability proportion is the most significant. From around 1985 onwards, z-positioning increased wide prevalence using evaluators, overseeing bookkeeper, field and database framework utilized for credit appraisal (eidleman, 2003). Yet, it is a mile's difficult to comprehend that more prominent significance as a remarkable proportion of severa research advocates as a side effect of the issue of limit. For instance, an organization might be moreover not to mention not to mention had a horrible liquidity proportions and may prompt liquidation. Certain hierarchical benefit indistinguishable can likewise escape from the risks of this limit is featured using poor liquidity proportion. Thus, the last stop, the translation of the utilization of customary proportion examination could not be right. Altman's 1968 variant took the accompanying structure:
Where:Z=overall index

A $=$ Working capital / Total Assets

$\mathrm{B}=$ Retained earnings/ Total Assets

$\mathrm{C}=\mathrm{EBIT} / \mathrm{Total}$ Assets

$\mathrm{D}=$ Market value of Equity/Book value of total debt

$\mathrm{E}=$ Sales / Total Assets

$\mathrm{Z}<$ then the firm classified as "Failed".

\subsubsection{Altman's Revised Z-Score Model:}

instead of without a doubt embeddings variables into the contemporary-day model to search for altman z-score pushing for a complete re-estimation of the model, replacing the predicted e-book price to market incentives d. this brings modifications inside the coefficients and at the concept of orders and related reduce-off score. model $\mathrm{z}$ rating modifications take accompanying structures:

in which:

$\mathrm{R} 1$ = (contemporary-day-current liabilities) / widespread belongings 
$\mathrm{R} 2$ = retained profits / preferred property

$\mathrm{R} 3$ = income before interest and taxes / fashionable property

$\mathrm{R} 4$ = ebook value of equity / popular liabilities

$\mathrm{R} 5$ = income / basic property

region discrimination:

$Z^{\prime}>2.9$ "Safe " Zone

$1.23<Z$ ' $<2.9$ "No conformation" Zone (Grey zone)

$\mathrm{Z}^{\prime}<1.23$ "Distress" Zone

\subsection{EMPIRICAL RESULTS:}

5 everyday agency share weighted via coefficients which may be used to look for the z-rating. weighted and summed to land in the well-known rating framed purpose for the order of the corporations to be one of the preceding employer (non-disturbed and indignant).

z-rating equation: $\mathrm{z}{ }^{\prime}=0.717 \mathrm{r} 1+0.847 \mathrm{r} 2+3.107 \mathrm{r} 3+$ zero.420r4 + 0.998r 5 .

zona accompanying segregation: $\mathrm{z}$ '> 2.9 "secure" place, $1.23<z^{\prime}<2.9$ "darkish" area and $z^{\prime}<1.23$ "trouble" zone. each one of the businesses which have a $z$ rating under
1.23 delegated enterprise in the location of ache, an business enterprise that has a $\mathrm{z}$ score of somewhere in the sort of 1.23 and a couple of.nine named organization in the region no version while the groups that have a rate above $2.9 \mathrm{z}$ named organizations included sector. ache inside the zone there may be a excessive opportunity of article eleven to a business enterprise, in zones version vulnerability exists if the business enterprise goes bankrupt or now not, even as in the included quarter there may be a low possibility of more and more agencies end up insolvent. the associated desk indicates the business enterprise of the conditions of the separation.

monetary pain edward altman forecast models placed 100 businesses, forty five groups inside the comfy region, 50 organizations in the location indistinct and five businesses are underneath the region misery.

\begin{tabular}{|c|c|c|c|}
\hline S. No & Company Name & Z-score & Zone \\
\hline 1 & ACROW INDIA LIMITED & 3.75 & Safe \\
\hline 2 & AKRUTI NIRMAN LIMITED & 1.97 & Grey \\
\hline 3 & ANANT RAJ INDUSTRIES LIMITED & 11.62 & Safe \\
\hline 4 & ANSAL BUILDWELL LIMITED & 2.89 & Grey \\
\hline 5 & $\begin{array}{l}\text { ANSAL HOUSING \& CONSTRUCTION } \\
\text { LIMITED }\end{array}$ & 1.98 & Grey \\
\hline 6 & $\begin{array}{lll}\text { ANSAL } & \text { PROPERTIES } & \& \\
\text { INFRASTRUCTURES LIMITED } & \\
\end{array}$ & 2.2 & Grey \\
\hline 7 & $\begin{array}{lll}\text { ARIHANT } & \text { FOUNDATIONS } \\
\text { HOUSING LIMITED } & \\
\end{array}$ & 1.96 & Grey \\
\hline 8 & ARTSON ENGINEERING LIMITED & 3.97 & Safe \\
\hline 9 & $\begin{array}{l}\begin{array}{l}\text { ASHIANA HOUSING } \\
\text { (INDIA) LIMITED }\end{array} \\
\end{array}$ & 12.29 & Safe \\
\hline 10 & ATLANTA LIMITED & 1.84 & Grey \\
\hline 11 & B L KASHYAP \& SONS LIMITED & 4.42 & Safe \\
\hline 12 & $\begin{array}{l}\text { BHAGHEERATHA ENGINEERING } \\
\text { LIMITED }\end{array}$ & 8.14 & Safe \\
\hline 13 & C \& C CONSTRUCTIONS LIMITED & 2.36 & Grey \\
\hline 14 & CCAP LIMITED & 4.48 & Safe \\
\hline 15 & CONART ENGINEERS LIMITED & 1.43 & Grey \\
\hline 16 & $\begin{array}{l}\text { CONSOLIDATED } \text { CONSTRUCTION } \\
\text { CONSORTIUM LIMITED }\end{array}$ & 8.24 & Safe \\
\hline 17 & $\begin{array}{lcc}\text { D } & \text { S KULKARNI } & \text { DEVELOPERS } \\
\text { LIMITED } & \\
\end{array}$ & 2.06 & Grey \\
\hline 18 & $\begin{array}{lll}\text { DCM } & \text { SHRIRAM } \\
\text { LIMITED } & \\
\end{array}$ & 2.23 & Grey \\
\hline 19 & DHURV ESTATES LIMITED & 5.18 & Safe \\
\hline 20 & DLF LIMITED & 1.45 & Grey \\
\hline 21 & $\begin{array}{l}\text { ELDECO HOUSING \& INDUSTRIES } \\
\text { LIMITED }\end{array}$ & 5.12 & Safe \\
\hline 22 & ELNET TECHNOLOGIES LIMITED & 2.03 & Grey \\
\hline 23 & ENGINEERS INDIA LIMITED & 3.29 & Safe \\
\hline 24 & $\begin{array}{lll}\text { ERA CONSTRUCTIONS } & \text { (INDIA) } \\
\text { LIMITED } & \\
\end{array}$ & 2.01 & Grey \\
\hline 25 & GAMMON INDIA LIMITED & 3.07 & Safe \\
\hline 26 & GARNET CONSTRUCTIONS LIMITED & 9.8 & Safe \\
\hline
\end{tabular}


International Journal of Recent Technology and Engineering (IJRTE) ISSN: 2277-3878, Volume-8, Issue-2S11, September 2019

\begin{tabular}{|c|c|c|c|}
\hline 27 & GAYATHRI PROJECTS LIMITED & 2.38 & Grey \\
\hline 28 & GMR INFRASTRUCTURES LIMITED & 4 & Safe \\
\hline 29 & HB ESTATE DEVELOPERS LIMITED & 3.69 & Safe \\
\hline 30 & $\begin{array}{l}\text { HINDUSTAN CONSTRUCTION } \\
\text { COMPANY LIMITED }\end{array}$ & 2.07 & Grey \\
\hline 31 & $\begin{array}{lcc}\text { HOUSING } & \text { DEVELOPMENT } \\
\text { INFRASTRUCTURES LIMITED } & \& \\
\end{array}$ & 2.91 & Safe \\
\hline 32 & IRCON INTERNATIONAL LIMITED & 7.42 & Safe \\
\hline 33 & ITD CEMENTATION INDIA LIMITED & 3.31 & Safe \\
\hline 34 & $\begin{array}{l}\text { IVR PRIME URBAN DEVELOPERS } \\
\text { LIMITED }\end{array}$ & 2.58 & Grey \\
\hline 35 & $\begin{array}{lll}\text { IVRCL } & \text { INFRASTRUCTURES } \\
\text { PROJECTS LIMITED } & \& \\
\end{array}$ & 3.02 & Safe \\
\hline 36 & JAI PRAKASH ASSOCIATES LIMITED & 3.06 & Safe \\
\hline 37 & JAIHIND PROJECTS LIMITED & 1.46 & Grey \\
\hline 38 & JMC PROJECTS (INDIA) LIMITED & 4.89 & Safe \\
\hline 39 & $\begin{array}{l}\text { KAMANWALA CONSTRUCTION \& } \\
\text { HOUSING LIMITED }\end{array}$ & 2.23 & Grey \\
\hline 40 & KCP LIMITED & 4.61 & Safe \\
\hline 41 & KEC INFRASTRUCTURES LIMITED & 3.51 & Safe \\
\hline 42 & LANCER HOLDINGS LIMITED & 2.74 & Grey \\
\hline 43 & LANCO INFRATECH LIMITED & 1.88 & Grey \\
\hline 44 & LARSEN \& TOUBRO LIMITED & 4.39 & Safe \\
\hline 45 & $\begin{array}{l}\text { LOK HOUSING \& CONSTRUCTIONS } \\
\text { LIMITED }\end{array}$ & 3.54 & Safe \\
\hline 46 & MADHUCON PROJECTS LIMITED & 2.51 & Grey \\
\hline 47 & $\begin{array}{l}\text { MAHINDRA LIFESPACES LIMITED } \\
\end{array}$ & 5.43 & Safe \\
\hline 48 & MARG CONSTRUCTIONS LIMITED & 1.93 & Grey \\
\hline 49 & MARTIN BURN LIMITED & 2.07 & Grey \\
\hline 50 & $\begin{array}{l}\text { MARUTI INFRASTRUCTURES } \\
\text { LIMITED }\end{array}$ & 2.85 & Grey \\
\hline 51 & MSK PROJECTS (INDIA) LIMITED & 1.92 & Grey \\
\hline 52 & $\begin{array}{l}\text { NAGARJUNA CONSTRUCTION } \\
\text { COMPANY LIMITED }\end{array}$ & 2.87 & Grey \\
\hline 53 & NARENDRA PROPERTIES LIMITED & 2.69 & Grey \\
\hline 54 & NAVKAR BUILDERS LIMITED & 4.87 & Safe \\
\hline 55 & NILA INFRASTRUCTURES LIMITED & 2.18 & Grey \\
\hline 56 & $\begin{array}{l}\text { NOIDA TOLL BRIDGE COMPANY } \\
\text { LIMITED }\end{array}$ & 1.61 & Grey \\
\hline 57 & OMAXE LIMITED & 1.93 & Grey \\
\hline 58 & ORBIT CORPORATION LIMITED & 2.58 & Grey \\
\hline 59 & ORIENT LIMITED & 2.84 & Grey \\
\hline 60 & PARSVNATH DEVELOPERS LIMITED & 2.13 & Grey \\
\hline 61 & PATEL ENGINEERING LIMITED & 2.43 & Grey \\
\hline 62 & PBA INFRASTRUCTURES LIMITED & 1.98 & Grey \\
\hline 63 & PENINSULA LAND LIMITED & 2.71 & Grey \\
\hline 64 & $\begin{array}{ll}\text { PETRON } & \text { ENGINEERING } \\
\text { CONSTRUCTION LIMITED }\end{array}$ & 6.35 & Safe \\
\hline 65 & $\begin{array}{lll}\text { PRAJAY } & \text { ENGINEERS } & \text { SYNDICATE } \\
\text { LIMITED } & & \\
\end{array}$ & 2.78 & Grey \\
\hline 66 & PRATHIBA INDUSTRIES LIMITED & 3 & Safe \\
\hline 67 & PRAVEEN PROPERTIES LIMITED & 1.56 & Grey \\
\hline 68 & $\begin{array}{l}\text { PRIME PROPERTY DEVELOPMENT } \\
\text { CORPORATION LIMITED }\end{array}$ & 3.22 & Safe \\
\hline 69 & PUNJ LLOYD LIMITED & 2.56 & Grey \\
\hline 70 & $\begin{array}{l}\text { PURAVANKARA PROJECTS LIMITED } \\
\end{array}$ & 2.03 & Grey \\
\hline 71 & $\begin{array}{lll}\text { RADHE } & \text { DEVELOPERS } & \text { (INDIA) } \\
\text { LIMITED } & & \\
\end{array}$ & 16.11 & Safe \\
\hline
\end{tabular}


FINANCIAL STATEMENT EVALUATION OF INDIAN CONSTRUCTION COMPANIES

\begin{tabular}{|l|l|l|l|}
\hline $\mathbf{7 2}$ & RAGHAVA ESTATES LIMITED & 1.34 & Grey \\
\hline $\mathbf{7 3}$ & RAINBOW FOUNDATIONS LIMITED & 2.01 & Grey \\
\hline $\mathbf{7 4}$ & RANDER CORPORATION LIMITED & 15.92 & Safe \\
\hline $\mathbf{7 5}$ & REGALIA REALTY LIMITED & 3.08 & Safe \\
\hline $\mathbf{7 6}$ & $\begin{array}{l}\text { RELIANCE INDUSTRIAL } \\
\text { INFRASTRUCTURES LIMITED }\end{array}$ & 3.63 & Safe \\
\hline $\mathbf{7 7}$ & ROMAN TARMAT LIMITED & 3.01 & Safe \\
\hline $\mathbf{7 8}$ & RUCHI INFRASTRUCTURES LIMITED & 0.18 & Distress \\
\hline $\mathbf{7 9}$ & $\begin{array}{l}\text { SAAG RR INFRASTRUCTURES } \\
\text { LIMITED }\end{array}$ & 3.26 & Safe \\
\hline $\mathbf{8 0}$ & $\begin{array}{l}\text { SIMPLEX INFRASTRUCTURES } \\
\text { LIMITE }\end{array}$ & 3.48 & Safe \\
\hline $\mathbf{8 1}$ & SIMPLEX PROJECTS LIMITED & 1.87 & Grey \\
\hline $\mathbf{8 2}$ & SOBHA DEVELOPERS LIMITED & 2.5 & Grey \\
\hline $\mathbf{8 3}$ & $\begin{array}{l}\text { SRINIVASA SHIPPING \& PROPERTY } \\
\text { DEV LIMITED }\end{array}$ & 3.86 & Safe \\
\hline $\mathbf{8 4}$ & $\begin{array}{l}\text { SUBHASH PROJECTS \& MARKETING } \\
\text { LTD }\end{array}$ & 3.22 & Safe \\
\hline $\mathbf{8 5}$ & TANTIA CONSTRUCTIONS LIMITED & 2.18 & Grey \\
\hline $\mathbf{8 6}$ & TEMPUS INFRA PROJECTS PVT LTD & 1.37 & Grey \\
\hline $\mathbf{8 7}$ & THAKKERS DEVELOPERS LIMITED & 17.08 & Safe \\
\hline $\mathbf{8 8}$ & $\begin{array}{l}\text { TRENCHLES } \\
\text { SERVICES }\end{array}$ & Grey \\
\hline $\mathbf{8 9}$ & TRIBHUVAN HOUSING LIMITED & 1.09 & Distress \\
\hline $\mathbf{9 0}$ & TRINETRA INFRA VENTURES LTD & 3.12 & Safe \\
\hline $\mathbf{9 1}$ & UNIQUEST INFRASTRUCTURE LTD & 2.38 & Grey \\
\hline $\mathbf{9 2}$ & UNITECH LIMITED & 2.96 & Safe \\
\hline $\mathbf{9 3}$ & $\begin{array}{l}\text { UNITED BREWERIES (HOLDINGS) } \\
\text { LIMITED }\end{array}$ & 2.02 & Grey \\
\hline $\mathbf{9 4}$ & UNITY INFRA PROJECTS LIMITED & 3.97 & Safe \\
\hline $\mathbf{9 5}$ & VALECHA ENGINEERING LIMITED & 1.22 & Distress \\
\hline $\mathbf{9 6}$ & VIATON INFRASTRUCTURE LTD & 0.61 & Distress \\
\hline $\mathbf{9 7}$ & VICTORIA ENTERPRICES LTD & 0.61 & Distress \\
\hline $\mathbf{9 8}$ & VIJAY SHANTI BUILDERS & 3.64 & Safe \\
\hline $\mathbf{9 9}$ & VIPUL LIMITED & 10.91 & Safe \\
\hline $\mathbf{1 0 0}$ & WIRTGEN INDIA PVT LTD & 2.19 & Grey \\
\hline & & & \\
\hline
\end{tabular}

\section{CONCLUSION}

given my research ends related withdrawn: diagnosed huge pointer seven elements of the improvement of their business enterprise liquidity factors, factors movement, dissolvability long term, the functionality, gainfulness, useful resource executives, variable stock. the outcomes display that the exhibition presentation development enterprise india in our examination has decreased grade by grade. the motive may be emergency monetary ad infinitum and even though normal stagnation. the level of commercial enterprise development of india's presentation confirmed that the pioneer feature of improvement has $40 \%$ of the companies underneath execution record zero. the legislature want to test cash-related situations of commercial organization development severely and attempt related activities. of a separate studies confirmed that forty five \% of corporations within the comfy sector, five $\%$ of corporations within the region misery and live underneath fifty five\% of corporations in the location fled. execution evaluation take a look at gives the idea for the government to embody the intervening time remedial sports, to start the sensible and consistent commercial enterprise survey is needed.

\section{REFERENCE}

1 abdullah (2004) "business development and improvement of monetary factors" the malaysian scene. "immoderate innovation malaysia, malaysia.

2 altman (1968) "the cash related proportions, separate examination and preference liquidation of the commercial enterprise commercial enterprise business enterprise", american companion account, september (1968), 23 (four) (589-609).

3 altman (2009). "assessing the execution of your agency", principia, 56 , sixteen-17.

4 expert pastry et al. (2002) "improvement in developing states inside the Nineteen Nineties: some issues on indigenous improvement groups". hbp diary, from nine. 21 to forty 4

5 balatbat et al. (2010) "comparable execution of open improvement agencies noted: australian evidence" issn, 28 (919-920), sydney. 
6 bandyopadhyay et al. (2011) "application of element assessment on monetary ratios and validation results based completely cluster evaluation - an empirical take a look at at the indian cement business enterprise". enterprise diary, 2 (three), thirteen-31.

7 barnes (1987) "studies and utilization of the percentage of the fee range, an audit article" diary of commercial enterprise agency and accounting of coins, from 14.449 to 461.

8 beaver (2011) "economic percent as signs of disappointment", mag of bookkeeping and research4 (1966), seventy one-111.

9 giant et al. (1995) all development groups via the downturn, macmillan, london.

10 chen (2009) "model for financial count on the execution of organizational development and improvement" asce, november (2009), taiwan.

11 chen et al. (1912) "the agency among wonderful participants within the production business enterprise of taiwan: essential achievement and failure elements", ieee, 1912-1917, taiwan.

12 cheng et al. (2005) "execution functionality scores taiwanese delivery enterprise" japanese asia society for transportation research, five (467-476) 2005.

13 cho et al (2001) "overall performance abilities assessment taiwan 's delivery company" east asian cultures for transportation studies, 4 (467-476)

14 edum et al. (1996) "a survey device share of the finances to assume quick people money owed". authorities improvement and financial factors, 14.189-498

15 eidleman (1995) "z-rating manually to approximate sadness" diary of cpa, sixty 5 (2), fifty -53 . 